\section{Sosyal Bilgiler Öğretiminde İşbirlikli Öğrenme Yaklaşımının Etkisi: Meta- Sentez Çalışması}

Türk Eğitim Bilimleri Dergisi

Makale Türü: Derleme

Makale Geliş Tarihi: 03.09.20

Makale Kabul Tarihi: 25.11.20

Makale Yayın Tarihi: 28.12.20

ORCID: 0000-0001-6296-978X,

0000-0002-5688-1316

\title{
Öz
}

Bu çalışmanın amacı, Sosyal Bilgiler öğretiminde İşbirlikli Öğrenme yaklaşımının etkilerini konu alan, son 10 yılda Türkiye'de ve diğer ülkelerde yapılmış çalışmaların çeşitli süreçlerden geçirilerek sunulmasıdır. Meta sentez (tematik içerik analizi) yöntemi ile yürütülen araştırmaya, tam metin olarak ulaşılabilen ve çalışmada belirlenen ölçütleri sağlayan 36 araştırma, çalışma kapsamına alınarak, belirlenen ölçütler eşliğinde meta-sentez çalışması yapılmıştır. Bu doğrultuda araştırmada yer alacak olan çalışmalara ulaşabilmek amacıyla, BAU (Bahçeşehir Üniversitesi), ERIC (Education Resources Information Center), Google Scholar ve Education Source veri tabanlarında alan yazın taraması yapılmıştır. Ulaşılabilen makaleler, çeşitli değişkenler doğrultusunda incelenmiş ve "doküman analizi" tekniği kullanılarak, analiz ve sentez süreçlerinden geçirilerek derlenmiştir. Meta-sentez sonucunda, sosyal bilgiler öğretiminde yapılandırmacı yaklaşım doğrultusunda kullanılan İşbirlikli Öğrenme yöntem ve tekniklerinin, hem akademik başarı, tutum, sosyal gelişim, motivasyon ve özyeterlik gibi öğrenmeyi etkileyen pek çok değişken üzerinde, hem de öğrencilerin okuduğunu anlama ve kavrama düzeylerinde olumlu yönde etki ve değişikliğe yol açtığ görülmüştür. Öğrencilerin hem bireysel hem de grup düzeyinde başarılarının artması dışında, demokratik tutumlarını geliştirme, özdenetim, tarihsel bilinç/duyarlılık ve empatik yaklaşım kazanma, çok kültürlülüğe dair kavramların öğretilmesi ve anlaşılması gibi konularda da öğrencileri geliştirici ve destekleyici olduğu bulunmuştur. Bu doğrultuda, yöntemin etkililiğine etki eden pek çok değişken vardır ve çalışma sonuçları, diğer çalışmalarla benzerlik göstermektedir.

Anahtar Sözcükler: İşbirlikli öğrenme, Akademik başarı, Sosyal bilgiler, Meta-sentez çalışması

\begin{abstract}
The purpose of this study is to review the studies about cooperative learning approach in teaching social studies and its effects in subject areas. The studies are selected from the publications in the last 10 years in Turkey and in other countries, using various processes. Thirt-six studies, which can be accessed in full text and meet the criteria determined beforehand were included in the study conducted with the meta-synthesis (thematic content analysis) method. In this direction, in order to reach the studies that will take place in the research, literature search was made in BAU (Bahçeşehir University), ERIC (Education Resources Information Center), Google Scholar and Education Source databases. The accessible articles were examined in line with various variables and compiled by using the "document analysis" technique, passing through analysis and synthesis processes. As a result of the meta-synthesis, it was determined that the methods and techniques used in social studies teaching in line with the constructivist approach positively effected and changed many variables affecting learning, such as academic achievement, attitude, social development, motivation and self-efficacy, as well as students' reading comprehension. In addition to the increase in students' achievement at both individual and group levels, it was found that students developed their democratic attitudes, gaining self-control, historical awareness/sensitivity and empathic approach, teaching and understanding the
\end{abstract}

\footnotetext{
${ }^{1}$ Gülistan Taş, Doktora Öğrencisi, Millı̂ Eğitim Bakanlığı, tasgulistan@gmail.com

${ }^{2}$ Kemal Akoğlu, Dr. Öğretim Üyesi, Boğaziçi Üniversitesi, kemalakoglu@gmail.com
} 
concepts of multiculturalism. In this direction, there are many variables that influence the effectiveness of the method and the study results are similar to other studies.

Keywords: Cooperative learning, Academic achievement, Social studies, Meta-synthesis study

\section{Giriş}

İşbirlikli öğrenme fikri on yıllardır öğrenme ortamlarında karşımıza çıkan bir öğrenme ve öğretme yöntemidir. Öğrenmenin zaman içerisinde değişen tanımı ile birlikte çeşitli yöntem ve teknikler, eğitim-öğretim ortamlarında gittikçe daha fazla yer almaya başlamıştır. İşbirlikli Öğrenme de bu yöntemlerden birisidir. Öğrenmeye bakış açısının zaman içerisindeki değişimi, öğrenmenin tanımına da yansımıştır. Ertürk (1985), öğrenmeyi bireylerde kalıcı izli bir davranış değişimi olarak görürken, Driscoll (1993) "Psychology of Learning for Instruction" adlı çalışmasında, öğrenmeyi, "insan performansı ve performans potansiyelindeki değişimin devamlılığı" (Driscoll, 2012, s.1) şeklinde tanımlamıştır. Zaman içerisinde, değişime yapılan bu vurgudan da anlaşıldığı üzere, bilginin değişimi, içeriği, değer kaynağı ve öğrenmeyle ilgili epistemolojik gelenekler gibi faktörler; kuramların çıkış noktası olan öğrenme tanım ve kapsamına da yansımıştır. Bu süreçte, davranışçı yaklaşımı benimseyenler, objektivist bir bakış açısıyla, bilginin deneyimlerle kazanıldığını savunurken; bilişselci yaklaşımı benimseyenler öğrenmede içsel süreçlere ağırlık vererek, bilginin deneyim ve düşünce ile kazanıldığını vurgulamış ve yapılandırmacılar ise pragmatist bir bakış açısıyla bilginin, öğrenen tarafından çevre ile etkileşime girmenin bir sonucu olarak inşa edildiğini yani oluşturulduğunu savunmuşlardır.

\section{Yapılandırmacılık ve İşbirlikli Öğrenme}

18. yüzyılda İtalyan filozof Giambattista Vico, bilginin inşası üzerine $1710^{\prime}$ da yayımladığı çalışma ile bilginin icat edilmekten daha ziyade, kişi tarafından inşa edildiğini ifade etmiştir. Vico "constructivist" terimini kullanarak, "Gerçeğin ölçütü ve kuralı, onu yapmaktır." ilkesini ortaya atmış (Glasersfeld, 1989; akt.Warrick, 2001) ve yapılandırmacılığın ilk sinyallerini vermiştir. Papert da, Vico gibi "yaşasın farklılıklar" -vivent les differences!- diyerek, bireysel farklılıklara dikkat çekmiştir (Papert ve Harel, 1991). Yapılandırmacılık, her ne kadar kökleri eskilere dayansa da, 20.yüzyılın sonlarına doğru yıldızı parlayan bir öğrenme felsefesi ve paradigması olmuştur. Konstrüktivizm, kurmacılık, inşacılık gibi farklı isimlerle de anılan kuram, felsefî ve psikolojik alt yapısını: Dewey, Mead, Piaget (Anderson, 2010), Montessori Bruner ve Vygotsky'den alarak (Campbell ve Richard, 2014), post-modern bir kuram olarak ortaya çıkarak; bilginin deneyimlerle oluştuğuna ve kişisel farklılıkların önemine vurgu yapmıştır.

Yapılandırmacılar, öğrenenin kendi deneyimlerini anlama çabası olarak bilginin yeniden yaratılmasını öneriyorlardı (Driscoll, 2012). Onlara göre bilgi, bireysel ve toplumsal olarak, öznel bir gerçekliğe dayalı olarak yapılandırılmaktaydı. Epistemolojik açıdan subjektif (öznel), öğretimsel 
açıdan ise tümdengelimciydiler (Ertmer ve Newby, 2013). Öğrenmenin bağlamsal doğasına, öğrenenler için taşıdığı anlama ve otantikliğe vurgu yapmışlardır. Yapılandırmacılık, kendisini destekleyen birçok kuramcıyı da beraberinde getirmiştir. Bunlar arasında: Vygotsky, Lave ve Wenger, Piaget, Bruner, Bransford ve CTGV (The Cognitive and Technology Group at Vanderbilt), Grabinger, Jonassen ve Spiro (Bruner 1990, akt. Yılmaz, 2011; Driscoll, 2012; Senemoğlu, 2018) gelmektedir. Farklı psikolog, filozof ve eğitim kuramcının görüşlerinden beslenen bu yaklaşım, farklı şekillerde açıklanmaya çalışılmış ve zaman içerisinde bilişsel (Piaget, Dewey, Bruner), sosyal (Vygotsky) ve radikal yapılandırmacılık (Glosersfeld) gibi farklı türleri de ortaya konmuştur.

Vygotsky'nin sosyal yapılandırmacılık teorisine göre öğrenme, kişinin kendinde var olan bilgisinin, yakın çevresiyle girdiği etkileşimin bir sonucu olarak, bu temel üzerine inşa ederek yapılandırdığı anlamlandırma sürecidir. Bu temelin, yapı taşları ise sosyo-kültürel çevrenin zenginliği ve deneyimler ile yakın ilişkilidir. Bu bağlamda kişi, içinde var olduğu sosyo-kültürel çevre ve yaşadığı deneyimlerden bağımsız olamayacağı için, bireyin bilgiyi yorumlaması, anlamlandırması, kendi bilgi iskelelerini veya çatılarını oluşturarak yapılandırması açısından söz konusu bağlam oldukça önemlidir. Çocuğun, aile içerisinde başlayan ve duyuşsal, bilişsel ve psikolojik gelişimine etki eden bu yakın çevre ve onun çekim alanı olan "yakınsak gelişim alanı (zone of proximal devlopment)", aile ile başlar, okul ortamında gelişmeye ve zenginleşmeye devam eder. Başlangıçta çocuk için scaffolding yani destekleme/iskele görevi gören ebeveynler ve aile yakınlarından oluşan bu gelişim alanı, çocuğun büyümesi ve eğitim ortamlarına girmesiyle birlikte daha da zenginleşerek gelişir. Eğitim ortamlarında öğretmen, bağımsız destekleyici/iskele (scaffolding) görevi görürken; öğrenci ise bilgiyi yapılandıran ve aktif bir şekilde başrolde yer alır. Başrolde olan bireyin, bilgiyi tüketmesi değil üretmesi beklenir (Kardaş, 2014; akt. Kardaş ve Cemal, 2015; Özkan, 2006). Bu süreçte, öğrenci kapasitesinin de ötesinde, gerçek veya otantik problemlere çözümler bulması için sık sık desteklenir. Öğretmen, aynı zamanda öğrenme etkinliklerinin gerçeğe yakın ve iyi yapılandırılmamış sorunlara odaklanmasını sağlayarak öğrencilerin aktif sorgulama yönünü ön plana çıkarmaya çalışır (Anderson, 2010). Bu doğrultuda, yapılandırmacı eğitim ortamlarında öğretmen, öğrencilerine otantik ortamlar, karmaşık problemler ve zengin yaşantılar sunar.

İşbirliği ve grup etkileşiminin etkileri 1920'lerden beri incelenmiş olmasına rağmen, özellikle D. Johnson, R. Johnson ve R. Slavin gibi bağımsız araştırmacıların da katkılarıyla gelişmiştir. 1960'larda, David Johnson işbirlikli ve rekabetçi teori üzerine çalışmalara başlamış, 1969'da David Johnson, kardeşi Roger Johnson ile birlikte "Cooperative Learning Center" 1 birlikte kurmuşlardır (Johnson ve Johnson, 2002). Bir diğer yandan, K-12 sınıflarında ortak bir öğretim yöntemi haline gelmeye başlamış olan işbirlikli öğrenme, teorik açıdan Piaget, Vygotsky ve Carroll gibi psikologların çalışmalarından da faydalanmıştır (Loeser, 2019). Yapılandırmacı yaklaşımla birlikte, eğitim ortamları 
öğrenci merkezli yeni strateji, yöntem ve tekniklere daha açık hale gelmiştir. Sınıf ve öğretmen merkezli olan geleneksel yöntemlere bağlı kalınarak yapılan öğretim faaliyetleri, zaman içerisinde yerini, yapılandırmacı yaklaşımla birlikte ortaya çıkan işbirlikli stratejilere bırakmıştır.

Geleneksel rekabetçi sınıf ortamlarına bir alternatif (Singh ve Agrawal, 2011) olan İşbirlikli Öğrenme, öğrenmeyi maksimum düzeyde gerçekleştirmek için farklı yetenekteki öğrencilerin, ufak gruplar şeklinde birlikte çalışarak, aynı hedefe ulaşmalarıdır (Johnson ve Johnson, 1994; akt. Efe, Hevedanll, Ketani, Çakmak ve Efe, 2008). İşbirlikli Öğrenme, küçük bir grupta çalışan öğrenciler arasında belirli bir görev veya ödev üzerinde çalışılarak, olumlu sosyal etkileşimlerin öne çıktığı bir öğretim stratejisidir. İşbirlikli Öğrenmenin, heterojen gruplar, ekip çalışması, dayanışma, pozitif bağımlılık, grup olma ve sorumluluk bilinci gibi pek çok kavramı da bünyesinde barındıran şemsiye bir yöntem ve strateji olduğunu söyleyebiliriz. İşbirlikli Öğrenme stratejileri, hem yüz yüze veya çevrimiçi eğitim ortamlarında hem de farklı disiplin ve sahalarda kullanılabilir. En yaygın kullanılan stratejiler arasında: Jigsaw, Birlikte Öğrenme, İşbirlikli Grup Okuma ve Kompozisyon, Grup Araştırması (GA), Birlikte Soralım Birlikte Öğrenelim (BSBÖ), Akademik Çelişki, (Bölükbaş, 2014; Loeser, 2019), Öğrenci Takım-Başarı Bölümleri ve Takımlar-Oyunlar-Turnuva (Slavin, 2016), Takım Temelli Öğrenme (TBL), Okuma-Yazma-Uygulama (OYU) gibi stratejileri sayabiliriz.

Ülkemizde, 2005 yılında yenilenen sosyal bilgiler programından sonra, kavram, beceri ve değerler eğitimine vurgu yapan bu program, sosyal bilgiler dersi için aktif bir sınıfı ortamı amaçlamaktadır (Ata 2006; akt. Akbulut 2013). Bu doğrultuda, yenilenen sosyal bilgiler programı ile birlikte sosyal bilgiler eğitiminde öğrencinin aktif katılımı ile yaparak yaşayarak öğrenmesi de ön plana çıkmış ve sadece sosyal bilgiler dersinde değil, pek çok derste İşbirlikli Öğrenme stratejileri kullanılmaya başlanmıştır. Geleneksel sınıflarla kıyaslandığı zaman, İşbirlikli Öğrenmenin akademik başarı, benlik saygısı, güven, verimlilik/etkililik, sosyal yetenekler, sosyal gruplar arası ilişkiler ve öğrenme sürecine yönelik genel tutumlar üzerinde doğrudan bir etkisi olduğuna dair pek çok çalışma vardır (Johnson ve Johnson, 2002). Bu çalışmalardan birisi de, Wall ve arkadaşları (2009) tarafından, geleneksel ve İşbirlikli Öğrenme sınıflarının karşılaştırılması üzerine yapılmıştır. Çalışma sonuçlarına bakıldığı zaman, İşbirlikli Öğrenme grup üyelerinin birlikte çalışması, birbirlerini dinlemesi, yeni düşünce ve çözümler açısından gruba katkıları, öğretmen ve diğer grup üyelerinden gelen övgüler açısından, geleneksel sınıflara göre pozitif yönde anlamlı bir farklılık bulunmuştur (Wall, Higgins, Glasner, Mahmout ve Gormally, 2009).

Johnson ve Johnson (2002) tarafından yapılan meta-analiz sonuçlarına göre 1970-1979 yılları arasında 15 çalışma, 1980-1989 arasında 49 çalışma ve 1990-2002 arasında ise İşbirlikli Öğrenme üzerine 29 çalışma yapılmıştır. Ülkemizde de İşbirlikli Öğrenme üzerine yapılan pek çok çalışma olmasına rağmen, ABD ile kıyaslandığında özellikle ülkemizde, sosyal bilgiler alanında yapılan 
çalışmaların daha geç tarihlerde yapılmış olduğunu görüyoruz. Bayır ve Bozkurt (2018), 2005-2010 yılları arasındaki 22 çalışmayı inceleyerek, İşbirlikli Öğrenme yöntem ve stratejilerinin sosyal bilgiler dersinde kullanımına dair bir meta-analiz çalışması yaparak, Sosyal Bilgiler dersinde işbirlikçi yaklaşımların kullanımının gittikçe arttığını ve bu yöntemin, öğrencilerin akademik başarısını olumlu etkilediğini ortaya koymuşladır. Yaşar ve arkadaşları (2015) tarafından yapılan meta-analiz çalışması ise, bu ders için uygulanan öğrenci merkezli yaklaşımların etkililiğinin, ders başarısına etkisini araştırmak amacıyla, 52 yüksek lisans ve doktora tezini incelemişler ve Bayır ve Bozkurt gibi İşbirlikli Öğrenmenin akademik başarı üzerindeki pozitif etkisini belirtmişlerdir (Yaşar, Köse, Göz ve Bayır, 2015). Bir diğer çalışma, Yıldız ve Kılıç (2018) tarafından, 2005-2016 arasında ülkemizde ilkokul düzeyinde sosyal bilgiler alanı için uygulanan öğretim programlarının, bazı boyutlarda öğretmen görüşleri doğrultusunda incelendiği bir meta-sentez çalışmasıdır. Çalışma sonuçlarına göre, En fazla sayıda belirtilen görüşün, uygulamada zaman yetersizliği olduğu görülmüştür.

Öğretim etkinliklerinin daha geniş bir çerçevede değerlendirilmesinin, sosyal bilgiler alanında uygulanan tekniklerin başarısının daha net görülmesi ve geliştirilmesi açısından alan çalışmalarının oldukça büyük bir önemi vardır. İşbirlikli öğrenmenin, sosyal bilgilere dair soyut kavramların öğrenimini kolaylaştırması ve kalıcılığı arttırması gibi yararları göz önünde tutulduğu zaman, ilgili yöntem ve stratejilerinin sosyal bilgiler alanındaki etkisine dair son 10 yllda literatürde geniş bir boyutta tarama yapılarak çalışıldığına dair bir meta-sentez araştırması karşımıza çıkmamıştır. Sosyal bilgiler alanında işbirlikli yöntemin etkililiğini görme, alan yazındaki yeri ve özelikle eğitimcilere rehber olup yol göstermesi açısından, sosyal bilgiler dersinde İşbirlikli Öğrenme tekniklerinin uygulandığı çalışmaların derlenerek meta-sentez şeklinde sunulmasının önemli olduğu düşüncesindeyiz.

\section{Yöntem}

\section{Çalışmanın Amacı}

Bu çalışmanın amacı, 2010-2020 yıllarında, sosyal bilgiler öğretiminde “İşbirlikli Öğrenme" yöntemi kullanılarak yapılan bilimsel çalışmaların (makale), sosyal bilgiler öğrenmelerine etkisine dair ilişkiyi belirlemek ve işbirlikli yönteme dair alan yazın için bir kaynakça sunmaktır. Bu doğrultuda çalışmalar, yıllara, ülkelere, amaçlara, kullanılan yöntemlere, veri toplama araçları, örneklem grupları ve büyüklükleri, kullanılan İşbirlikli Öğrenme teknikleri ve sonuçları açısından, analiz edilerek sistematik bir derleme ortaya konulmaya çalışılmıştır. Böylece araştırmacılar alan ve yönteme dair son 10 yıla ait çalışmaları, bütüncül bir şekilde görerek, gelecek çalışmaları daha iyi planlayabileceklerdir. 


\section{Araştırma Deseni}

Araştırmada, işbirlikli öğrenme yaklaşımının, sosyal bilgiler ders ve alanına etkisini inceleyen çalışmaların sonuçlarının birleştirilmesi amacıyla meta-sentez (tematik içerik analizi) yönteminden yararlanılmıştır. Polat ve Ay (2016)'a göre: “Meta-sentez araştırmaları, belirli bir alanda yapılan çalışmaların nitel bulgularının; yorumlanmasını, değerlendirilmesini, benzer ve farklı yönlerinin ortaya konulmasını ve yeni çıkarımlar yapılmasını amaçlayan çalışmalardır." (s.52). Çalışmada taranan alan yazın doğrultusunda, sosyal bilgiler öğrenimine dair işbirlikli öğrenme yönteminin etkisine ilişkin görüşler derlenerek, eleştirel bir bakış açısıyla sentezlenerek yorumlanmaya çalışılmıştır.

\section{Veri Kaynağı}

Araştırmanın evreni, 2010-2020 yılları arasında işbirlikli öğrenme konusunda yapılan, BAU, ERIC, Google Scholar ve Education Source veri tabanlarında yer alan Türkçe ve İngilizce "işbirlikli öğrenme, kooperatif öğrenme, akademik başarı, sosyal bilgiler, meta-sentez çalışması" anahtar sözcükleriyle taranarak tam metnine ulaşılabilen 36 çalışmadan oluşmaktadır. Araştırma, evren üzerinde gerçekleştirilmeye çalışılmış ve çalışma kriterlerine uyma koşulu taşıyan her makaleye örneklem içerisinde yer verilmiştir. Ancak dışlama kriterlerine göre uygun olmayan çalışmalar ise araştırmaya alınmamıştır.

\section{Verilerin Toplanma Süreci ve Analizi}

Çalışmaları belirlemek amacıyla, bahsedilen veri tabanlarında toplu tarama yapılmış ve veriler, 2020 yılı Nisan ayı içerisinde toplanmıştır. Yapılan sistematik derleme, konuyla ilgili araştırma makalelerinin, geriye dönük olarak taranması biçiminde gerçekleştirilmiştir. Çalışmada yer alacak olan araştırmalara ulaşabilmek amacıyla "işbirlikli öğrenme, kooperatif öğrenme, akademik başarı, ders başarısı, sosyal bilgiler, sosyal bilimler, constructivist learning approach, cooperative learning, collaborative learning, academic acchievement, social studies, social sciences" anahtar kelimeleri kullanılarak, Türkçe ve İngilizce çeşitli kombinasyonlarda ilgili veri tabanlarında taramalar yapılmıştır. Araştırma kapsamına, Mart 2010-Mart 2020 tarihleri arasındaki zaman diliminde Türkçe veya İngilizce dillerinde yazılarak BAU, ERIC, Google Scholar ve Education Source'da ulaşılabilen, hakemli bilimsel dergilerde yayımlanmış olan makaleler alınmıştır. Araştırma kapsamına, Türkiye ve başka ülkelerde öğrenim gören öğrenciler ile gerçekleştirilmiş çalışmalar dâhil edilmiştir. Konuyla ilgili ülke içinde yapılan tezlere ulaşılmasına rağmen yurt dışında yayınlanan tezler çalışmaya alınmamıştır. Bunda erişimde yaşanan güçlügün çalışmanın geçerliliğini düşüreceği ve yapılan metasentez'in kapsamından kaynaklı endişeler etkili olmuştur. Ayrıca kongrelerde sunulan bildiriler, kitaplar, raporlar ve sadece özetine ulaşılabilen makaleler de bu sistematik derlemeye dâhil edilmemiştir. Veri tabanlarındaki taramalar sonucunda 36 adet makaleye ulaşılarak bu makaleler 
değerlendirmeye alınmış ve elde edilen bulguların analizi yapılarak sunulmaya çalışılmıştır. İlk aşamada işbirlikli öğrenmeye dair alan uzmanı ile görüşülerek belirlenen kavramlar tarama ve seçim kriterlerine göre kodlanmış, bu bağlamda temalar ortaya çıkarılmıştır. Araştırma kapsamına alınan çalışmalar “Makale1:M1, Makale2:M2..." şeklinde kodlanarak, Excel'e aktarılmış ve eş zamanlı olarak iki araştırmacı tarafından araştırma sorularının cevapları Excel tablosuna girilerek, karşılaştırılmıştır. Sonrasında ise veriler derlenerek sunulmaya çalışılmıştır.

\section{Bulgular}

Araştırmanın bu bölümünde; sosyal bilgiler öğreniminde İşbirlikli Öğrenme yöntemini kullanarak yapılan çalışmalara dair araştırma sonucunda elde edilen bulgulara ve yorumlara yer verilmiştir.

\section{1. Çalışmaların Yıllara Göre Dağılımı}

Şekil 1'de çalışmalarının yapıldığı yıllara ait dağılımlar verilmiştir.



Şekil 1. Çalışmaların Yıllara Göre Dağılımı

Şekil 1 incelendiğinde, 2010 yılına ait hiçbir çalışmaya rastlanmamıştır. 2011'de 1 çalışma (M35), 2012'de 1 (M30), 2013'de 3 (M26, M27, M36), 2014'de 4 (M22, M23, M25, M34), 2015'de 8 (M16, M17, M18, M19, M20, M21, M24, M31), 2016'da 6 (M10, M11, M12, M14, M15, M28), 2017'de 6 (M6, M7, M8, M9, M13, M33), 2018'de 4 (M2, M3, M4, M5), 2019'da 2 çalışma (M1, M32) ve 2020'de ise 1 çalışma (M29) bulunmuştur. 2010 yılına ait ise hiç çalışma bulunamamıştır. Çalışmaların 28'inin (\% 77.7) yani \% 75'den fazlasının 2014-2017 yılları arasında gerçekleştiği; en çok çalışmanın 8 (\% 22.2) adet olarak 2015 yılında ve en az çalışmanın ise 2010-2012 yılları arasında yapıldı̆̆ı görülmektedir. 


\section{Araştırmaların Ülkelere Göre Dağılımı}

Araştırma kapsamında ele alınan çalışmaların ülkelere göre dağılımları Şekil 2'de verilmiştir.

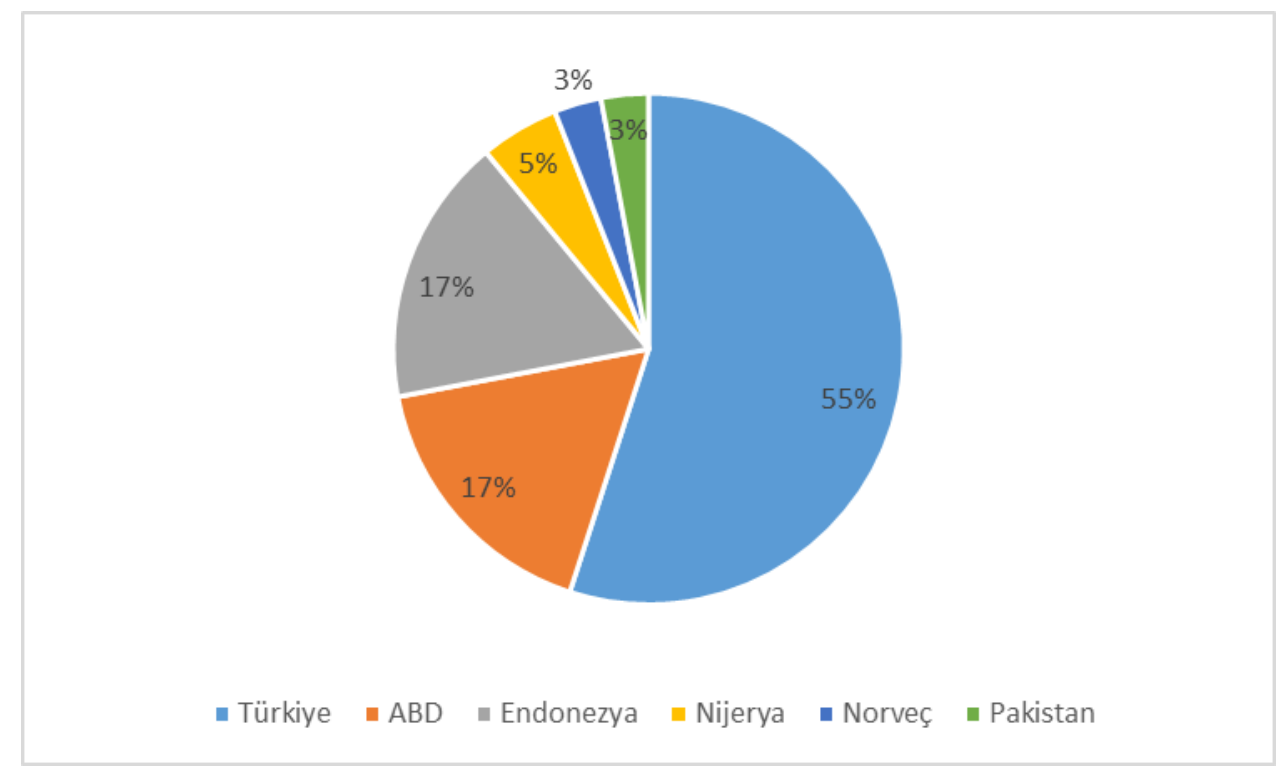

Şekil 2. Çalışmaların Ülkelere Göre Dağılımları

Şekil 2 incelendiğinde, İşbirlikli Öğrenmeye ilişkin yapılan çalışmaların 20'sinin (\% 55.5) yani yaklaşık yarısından fazlasının Türkiye'de (M1, M2, M6, M9, M10, M11, M12, M13, M14, M15, M17, M23, M24, M28, M29, M30, M32, M33, M34, M36) yapıldığı görülmüştür. ABD (M18, M19, M20, M21, M22, M27) ve Endonezya (M3, M4, M7, M8, M16, M31)'ya ait 6'şer adet, Nijerya'ya ait 2 çalışma (M25, M26), Norveç (M5) ve Pakistan (M35)'a ait ise 1'er çalışma yapılmıştır.

\section{3. Çalışmaların Amaçlarına Ait Veriler}

Tablo 1 incelendiğinde en fazla çalışmanın, yöntemin başarıya etkisi üzerine yapıldı̆̆ını görüyoruz. 17 çalışma yani çalışmaların yaklaşık yarısı, Sosyal Bilgiler alanında İşbirlikli Öğrenme yönteminin başarıya etkisini incelemiştir. İşbirlikli öğrenme yöntemi ile geleneksel öğrenme metotlarının öğrenmeye etkisi açısından karılaştırılması üzerine 15 çalışma, İşbirlikli Öğrenme yönteminin tutuma etkisi üzerine 6 çalışma, yönteminin uygulanmasına dair öğrenci görüşleri üzerine 5 çalışma ve yönteminin içerik kazanımına etkisi üzerine 4 çalışma yapılmıştır. İlgili konuda en az çalışmanın motivasyon, sosyal beceri kazanımı, epistemolojik inanç, üst düzey düşünce becerileri ve öğrenme çıktıları, öz-yeterlilik inancı, öz-denetim becerileri ve yöntemin uygulanmasındaki engellere dair öğretmen görüşleri üzerine olduğu görülmüştür. 
Tablo 1. Çalışmaların Amaçlarına Ait Veriler

\begin{tabular}{ll}
\multicolumn{1}{c}{$\begin{array}{c}\text { Amaçlar } \\
\text { (Issbirliğine Dayalı Öğretimin) }\end{array}$} & Çalışmalar \\
\hline Akademik başarıya etkisi & $\begin{array}{l}\text { M1, M2, M3, M6, M9, M10, M15, M22, M23, } \\
\text { M24, M26, M27, M28, M29, M31, M34, M35 }\end{array}$ \\
\hline Geleneksel metotlarla karılaştırılması & $\begin{array}{l}\text { M14, M18, M19, M20, M21, M23, M24, M25, } \\
\text { M26, M28, M30, M33, M34, M35, M36 }\end{array}$ \\
\hline Motivasyona etkisi & M3, M16 \\
\hline Tutuma etkisi & M9, M11, M25, M26, M32, M33 \\
\hline İçerik kazanımına etkisi & M18, M19, M20, M22 \\
\hline Sosyal becerilere etkisi & M12 \\
\hline Epistemolojik inanca etkisi & M36 \\
\hline Öz-yeterlik ve öz-denetime etkisi & M30 \\
\hline Üst düzey düşünme becerilerine & M7, M8 \\
\hline Uygulama engellerine dair öğretmen görüşleri & M4 \\
\hline Uygulanmasına dair öğrenci görüşleri & M5, M13, M14, M17, M32 \\
\hline
\end{tabular}

\section{4. Çalışmaların Yöntemlerine Ait Veriler}

Çalışmaların kullanılan yöntemlere ait dağılımlar Tablo 2'de verilmiştir.

Tablo 2. Çalışmaların Yöntemleri

\begin{tabular}{|c|c|c|c|c|}
\hline & Yöntem & & Çalışmalar & $f$ \\
\hline \multirow{3}{*}{ 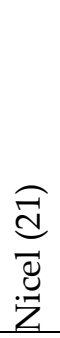 } & \multirow[b]{2}{*}{ Deneysel Desen } & $\begin{array}{l}\text { Ön-Sontest Kontrol } \\
\text { Gruplu Desen }\end{array}$ & $\begin{array}{l}\text { M15, M18, M19, M20, M23, M24, } \\
\text { M28, M30, M33, M35 }\end{array}$ & \multirow{3}{*}{$\% 58.3$} \\
\hline & & $\begin{array}{l}\text { Ön-Sontest Kontrol } \\
\text { Grupsuz Desen }\end{array}$ & M10, M11, M12 & \\
\hline & $\begin{array}{l}\text { Yar1-Deneysel } \\
\text { Desen }\end{array}$ & $\begin{array}{l}\text { Ön-Sontest Kontrol } \\
\text { Gruplu Desen }\end{array}$ & $\begin{array}{l}\text { M2, M3, M9, M25, M26, M29, M32, } \\
\text { M36 }\end{array}$ & \\
\hline \multirow{4}{*}{ 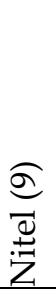 } & $\begin{array}{l}\text { Eylem } \\
\text { Araştırması }\end{array}$ & & M1, M7, M8, M16, M31 & \multirow{4}{*}{$\% 25$} \\
\hline & İçerik Analizi & & M13, M17 & \\
\hline & Betimsel Analiz & & M4 & \\
\hline & Etnografi & & M5 & \\
\hline \multirow{2}{*}{ 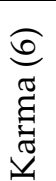 } & Açıklayıcı Desen & $\begin{array}{l}\text { Sıralı } \quad \text { Açıklayıcı } \\
\text { Desen }\end{array}$ & M6 & \multirow[t]{2}{*}{$\% 16.6$} \\
\hline & & Belirtilmemiş & M14, M21, M22, M34, M27 & \\
\hline
\end{tabular}

Nicel yöntemin kullanıldığg 21 çalışma (\% 58.3), nitel yöntemin kullanıldığı 9 çalışma (\% 25) ve karma yöntemin kullanıldığı 6 çalışma (\% 16.6) olduğu görülmüştür. Nicel yöntemlerde ağırlıklı 
olarak öntest-sontest kontrol gruplu deneysel desen kullanılmıştır. Nitel yöntemlerde ise eylem araştırmaları daha fazla tercih edilmiştir. Karma çalışmaların nicel boyutunda, genellikle deneysel desen tercih edilirken, bazı nitel ve karma çalışmaların desenlerinden ise bahsedilmemiştir.

\section{5. Çalışmaların Örneklem Gruplarına Ait Veriler}

Tablo 3'te çalışmaların örneklem gruplarına göre dağılımları verilmiştir.

Tablo 3. Çalışmaların Örneklem Grupları

\begin{tabular}{|c|c|c|}
\hline Örneklem Grubu & Çalışmalar & f \\
\hline İlkokul 4.sınıf & M1, M34 & $\% 5$ \\
\hline İlköğretim (Ortaokul) 5.sınıf & M3, M9, M16, M29, M31 & $\% 60$ \\
\hline $6 . \sin i f$ & M10, M11, M12, M13, M23, M24, M28, & \\
\hline 6-7.sinif & M5 & \\
\hline 7.sinif & M6, M14, M15, M17, M30 & \\
\hline 8.sinif & M7, M8, M19, M21, M27, M35 & \\
\hline Ortaokul (İlköğretim II.Kademe) & M25, M26 & $\% 5$ \\
\hline Lise 9.sinif & M32, M33 & $\% 12.5$ \\
\hline Lise 11.sınif & M18, M20, M22 & \\
\hline Öğretmen Adayı & M2, M36 & $\% 5$ \\
\hline Öğretmen & M4, M19, M20, M22, M27 & $\% 12.5$ \\
\hline
\end{tabular}

Araştırma kapsamında en fazla 24 çalışma (\% 60) ortaokul düzeyinde gerçekleşirken, sınıfı belli olmasa da ortaokul düzeyinde gerçekleşen iki çalışmaya (\% 5) daha rastlanmıştır. İlkokulda sadece iki çalışma (\% 5) yapılırken, ilkokul (\% 5) ve lise düzeyindeki (\% 12.5) örneklemler oldukça azdır. Yine üniversite düzeyindeki öğretmen adayları (\% 5) ve öğretmenler (\% 12.5) ile yapılan çalışmalar da düşük bir düzeydedir.

\section{6. Çalışmaların Örneklem Büyüklügüne Ait Veriler:}

Çalışmaların örneklem büyüklükleri Tablo 4'te verilmiştir.

Tablo 4. Çalışmaların Örneklem Büyüklüğü

\begin{tabular}{lll}
\hline Örneklem Büyüklüğü & Çalışmalar & f \\
\hline $1 \leq \mathrm{N} \leq 10$ & $\mathrm{M} 5$ & $\% 2.7$ \\
$11 \leq \mathrm{N} \leq 30$ & $\mathrm{M} 1, \mathrm{M} 7, \mathrm{M} 13, \mathrm{M} 17, \mathrm{M} 18, \mathrm{M} 30$ & $\% 16.6$ \\
$31 \leq \mathrm{N} \leq 50$ & $\mathrm{M} 3, \mathrm{M} 6, \mathrm{M} 16, \mathrm{M} 33, \mathrm{M} 34, \mathrm{M} 35$ & $\% 16.6$ \\
$51 \leq \mathrm{N} \leq 100$ & $\mathrm{M} 9, \mathrm{M} 10, \mathrm{M} 11, \mathrm{M} 12, \mathrm{M} 14, \mathrm{M} 23, \mathrm{M} 24, \mathrm{M} 28, \mathrm{M} 29, \mathrm{M} 31, \mathrm{M} 32$ & $\% 30.5$ \\
$101 \leq \mathrm{N} \leq 150$ & $\mathrm{M} 2, \mathrm{M} 15, \mathrm{M} 25, \mathrm{M} 26$ & $\% 11.1$ \\
$151 \leq \mathrm{N} \leq 200$ & $\mathrm{M} 21, \mathrm{M} 36$ & $\% 5.5$ \\
$350 \leq \mathrm{N} \leq 400$ & $\mathrm{M} 19$ & $\% 2.7$ \\
$401 \leq \mathrm{N} \leq 500$ & $\mathrm{M} 22, \mathrm{M} 27$ & $\% 5.5$ \\
$800 \leq \mathrm{N} \leq 850$ & $\mathrm{M} 20$ & $\% 2.7$ \\
Belirtilmemiş & $\mathrm{M} 4, \mathrm{M} 8$ & $\% 5.5$ \\
\hline
\end{tabular}


İşbirlikli Öğrenme uygulamalarının gerçekleştirildiği grupların örneklem büyüklükleri, belli aralıklarla gruplandırılarak ifade edilmiştir. Buna göre örneklem büyüklüğü en az yani $1 \leq \mathrm{N} \leq 10$ arasında olan çalışma sayısı 1 iken, $51 \leq \mathrm{N} \leq 100$ örnekleminde 11 çalışma (\% 30.5), $11 \leq \mathrm{N} \leq 30$ ile $31 \leq \mathrm{N} \leq 50$ kişilik örneklemlerde toplamda 12 çalışma (\% 33.2) oranlarında gerçekleştirilmiştir. $51 \leq \mathrm{N} \leq 100$ kişilik


çalışma (\% 33.3) yapılmıştır. $101 \leq \mathrm{N} \leq 850$ arasında örneklem sayısına sahip olan araştırmaların sayısı ise 10 (\% 27.7)'dur. 2 Çalışmanın (\% 5.5) ise örneklem sayısı belirtilmemiştir.

\section{7. Çalışmaların Veri Toplama Araçlarına Ait Veriler}

Çalışmaların veri toplama araçlarına ait dağılımlar Tablo 5'te verilmiştir.

Tablo 5. Çalışmaların Veri Toplama Araçlarına Ait Veriler

\begin{tabular}{|c|c|c|c|}
\hline \multicolumn{2}{|c|}{ Veri Toplama Araçları } & Çalışmalar & $\mathbf{f}$ \\
\hline \multicolumn{2}{|c|}{ Testler (Başarı Testleri) } & $\begin{array}{l}\text { M2, M6, M9, M10, M14, M15, M18, M19, } \\
\text { M20, M21, M22, M23, M24, M25, M26, } \\
\text { M28, M29, M30, M32, M35 }\end{array}$ & $\% 32$ \\
\hline \multirow{11}{*}{  } & Yöntem Görüş Ölçeği & M2 & \multirow{11}{*}{$\% 19.3$} \\
\hline & Demokratik tutum Ölçeği & M9, M11 & \\
\hline & Sosyal Beceri Ölçeği & M12 & \\
\hline & Jigsaw Görüş Ölçeği & M14 & \\
\hline & Öz-değerlendirme Ölçeği & M17 & \\
\hline & İşbirlikli Öğrenme Ölçeği & M29 & \\
\hline & Sosyal Bilgiler Dersi Tutum Ölçeği & M29 & \\
\hline & Öz-yeterlilik İnancı Ölçeği & M30 & \\
\hline & Öz-düzenleme Becerileri Ölçeği & M30 & \\
\hline & Tarih Dersi Tutum Ölçeği & M32 & \\
\hline & Tarihi Çevre Görüş Ölçeği & M33 & \\
\hline \multicolumn{2}{|c|}{$\begin{array}{l}\text { Görüşme/ Mülakat } \\
\text { (Yarı Yapılandırılmış Görüşme Formu) }\end{array}$} & $\begin{array}{l}\text { M1, M4, M7, M8, M13, M16, M17, M21, } \\
\text { M33, M34 }\end{array}$ & $\% 16.1$ \\
\hline \multicolumn{2}{|c|}{ Gözlem } & M4, M5, M6, M7, M8, M16, M22, M27, M31 & $\% 14.5$ \\
\hline \multicolumn{2}{|c|}{ Anket } & M3, M7, M8, M16, M36 & $\% 8$ \\
\hline \multicolumn{2}{|c|}{ Video/Ses Kayıtları } & M1, M5, M21 & $\% 4.8$ \\
\hline \multicolumn{2}{|c|}{ Dokümantasyon } & M7, M8 & $\% 3.2$ \\
\hline \multicolumn{2}{|c|}{ Öğrenci Günlükleri } & M1 & $\% 1.6$ \\
\hline
\end{tabular}

Tablo 5 incelendiğinde, çalışmalarda en çok kullanılan veri toplama araçları sırasıyla, başarı testleri 20 çalışma (\% 32), ölçek 12 (\% 19.3), görüşme/mülakat 10 (\% 16.1) ve gözlem 9 (\% 14.5) olarak belirlenmiştir. Diğer veri toplama araçları arasında anket 5 çalışmada (\% 8), video/ses kayıtları 3 (\% 4.8), dokümantasyon 2 (\% 3.2) ve öğrenci günlükleri 1 çalışmada (\% 1.6) kullanılarak, en az tercih edilen araçlar olmuştur. Şimşek (2007)'in hazırladığı "Yöntem Görüş Ölçeği” hariç, araştırmacılar, başka araştırmacıların hazırladığı ölçekleri kullanmışlardır. Bunlar: Şahiner (2008) ve Ural (2010)’ın 
“Demokratik tutum Ölçeği", Tuncel (2006)'in "Sosyal Beceri Ölçeği”, Uğur (2009)'un “Jigsaw Görüş Ölçeği”, MEB’in “Öz-değerlendirme Ölçeği”, Gömleksiz ve Kan (2013)’ın “İşbirlikli Öğrenme Ölçeği”, Ionnou ve vd., (2006)'nin “Öz-yeterlik İnancı Ölçeği”, Zimmerman (1989)’ın “Öz-düzenleme Becerileri Ölçeği”, Safran (2006)'ın “Tarih Dersi Tutum Ölçeği”, Alkış ve Oğuzoğlu (2005)'nun “Tarihi Çevre Görüş Ölçeği”, El-Deghaidy ve Nouby (2008)'in “Sosyal Bilgiler Dersi Tutum Ölçeği”dir.

\section{8. Çalışmalarda Kullanılan İşbirlikli Öğrenme Tekniklerine Ait Veriler}

Çalışmaların işbirlikli öğrenme tekniklerine ait dağılımlar Şekil 3’te verilmiştir.

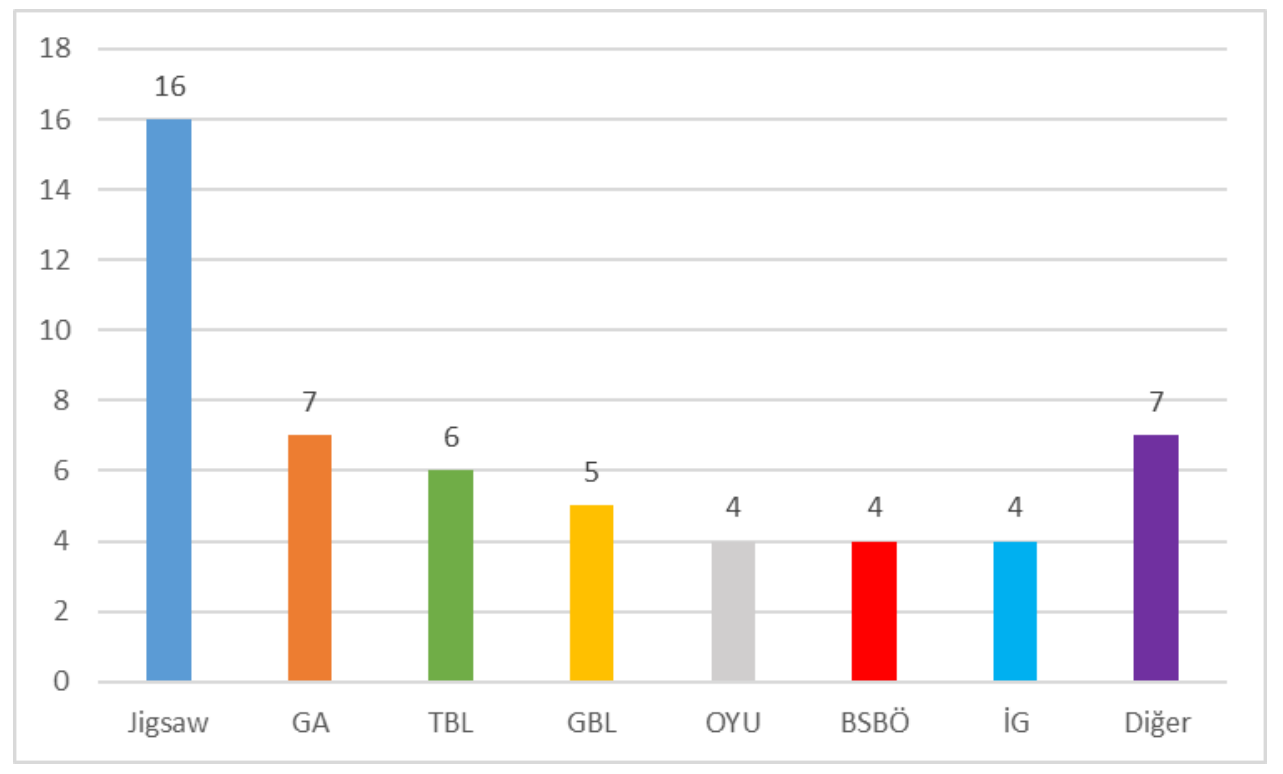

Şekil 3. Çalışmalarda Kullanılan İşbirlikli Öğrenme Stratejileri

Şekil 3 incelendiğinde, çalışmalarda kullanılan İşbirlikli Öğrenme teknikleri şunlardır: Jigsaw 16 çalışma (\% 30) (M2, M6, M10, M11, M12, M13, M14, M23, M24, M25, M26, M28, M30, M31, M32, M36), Grup Araştırması (GA) 7 (\%13.2) (M10, M11, M12, M23, M24, M33, M36), Takım Temelli Öğrenme (TBL) 6 (\% 11.3) (M18, M19, M20, M22, M27, M34), Oyun Temelli Öğrenme/Oyunlaştırma (GBL) ise 5 (\% 9.4) (M5, M21, M29, M16, M17) çalışma ile en çok kullanılan stratejilerdir. OkumaYazma-Uygulama (OYU) 4 çalışma (\% 7.5) (M10, M11, M12, M1), Birlikte Soralım Birlikte Öğrenelim (BSBÖ) 4 (\% 7.5) (M2, M9, M17, M28), İşbirlikli Grup Okuma-Yazma-Sunma (OYS) 2 (\% 3.7) (M24, M36), Yuvarlak Masa (Round Table) 2 (\% 3.7) (M7, M8), Ralli Koçu (Rally Koçu) 1 (\% 1.8) (M8), Atlı Karınca (Carousel Feedback) 1 (\% 1.8) (M7) ve Numaralı Beraber Öğrenme Modeli (NHT) ise 1 çalışma (\% 1.8) (M4), en az kullanılan stratejiler olarak belirlenmiştir.

\section{Araştırmalardan Elde Edilen Sonuçlar}

İncelenen araştırmaların sonuçları detaylı bir şekilde incelenerek Tablo 6'da gösterilmiştir. Yapılandırmacı yaklaşım doğrultusunda İşbirlikli Öğrenmenin, geleneksel metotlara göre daha başarılı bir yöntem olduğuna dair çeşitli çalışmalar (M1, M6, M9, M14, M18, M19, M20, M21, M22, 
M23, M25, M26, M29, M30, M33, M34, M36) incelenmiştir. Yapılan çalışmalarda, IOÖ ile ilgili yürütülen deneysel çalışma ve araştırma sonuçlarına göre (M2, M3, M4, M6, M7, M8, M9, M10, M13, M14, M15, M17, M20, M22, M23, M25, M26, M29, M30, M31, M32, M33, M34) İşbirlikli Öğrenmenin, öğrencilerin sosyal bilgiler alanında akademik başarı üzerinde olumlu etkisinin olduğu görülmektedir. Bu sonuçların yanı sıra az sayıda çalışma (M24, M35) İşbirlikli Öğrenmenin, öğrencilerin sosyal bilgiler alanında başarısına olumlu veya olumsuz bir etkisinin olmadığı sonucuna ulaşmıştır. Bu araştırmalarda çıkan farklılığın sonuçları araştırıldığında ise öğretmen, öğrenci ve eğitim ortamlarından kaynaklanan bazı sorunlar ifade edilmiştir. Öğretmenlerin geleneksel ve alışık oldukları yöntemleri uygulamanın getirdiği rahatlığı bırakmak istememeleri (M19), sınıf yönetimi (M19, M21, M26, M32, M33) ve zaman yönetiminde (M2, M4) yaşanılan zorluklar İşbirlikli Öğrenme uygulamalarında görülen bazı engeller arasındadır. İşbirlikli Öğrenme yöntemlerinin uygulanması hakkında neler düşündüklerini ortaya koymak açısından öğrenci görüşleri incelendiğinde ise İşbirlikli Öğrenme çalışmalarında, grup üyelerinin sorumluklarını yerine getirmemeleri (M2, M4, M13, M24, M32, M33), grup bilincinin oluşmaması (M2, M13, M24), grup üyeler arasında hirs, rekabet ve ödüle bağlı olarak oluşan negatif sinerji ve buna bağlı oluşan baskıyla birlikte ortaya çıkan motivasyon kaybı (M13), iletişim problemleri (M4, M32), İşbirlikli Öğrenme tekniklerinin sıkıcı ve zaman kaybı görülmesi (M6); bazı öğrencilerin işbirlikli uygulamalara katılmak istememesi (M4, M6, M24) ve özgüven sorunu yaşaması (M4, M31), derse dair konu eksiğinin veya gerekli hazırlığı yapmamış olması (M2, M6, M13, M22, M24) gibi içerikle ilgili yaşanılan sorunlar da ifade edilmiştir. Ayrıca sınıf ortamının fiziksel şartlarının yetersizliği (M2, M4) ve kalabalık sınıfların varlığı da (M4, M32), sosyal bilgilerde İşbirlikli Öğrenme uygulamalarında olumsuz görüşlere neden olmuştur.

Yapılan incelemelerde, İşbirlikli Öğrenme uygulamalarının kullanıldığı işbirlikli gruplardaki öğrencilerin, arkadaşlık ilişkilerini geliştirerek sosyal beceri ve yeteneklerini geliştirdikleri (M1, M2, M5, M8, M12, M13, M14, M17, M19, M25, M26, M27, M28, M29, M30, M31, M32, M33, M34), iletişimi ve etkileşimi geliştirerek; işbirliği, olumlu dayanışma, sorumluluk alma, yardımlaşma ve saygı gibi konularda olumlu bir etkiye sahip olduğunu ortaya koymuştur (M1, M2, M3, M4, M5, M6, M7, M8, M10, M12, M13, M14, M15, M16, M17, M18, M20, M22, M23, M25, M26, M29, M30, M31, M32, M33, M34). Çalışmalara göre öğrencilerin aktif olarak derse katılımını arttıran İşbirlikli Öğrenme uygulamalariyla (M1, M2, M4, M7, M10, M13, M14, M16, M17, M18, M21, M22, M23, M25, M26, M28, M30, M31, M32, M33, M34), dersler daha zevkli ve eğlenceli geçmekte (M1, M5, M6, M13, M16, M17, M21, M27, M29, M31, M32, M33, M34) ve etkinliklerde ödülün de olumlu bir etkiye sahip olduğu (M10, M13, M29, M30) ifade etmektedir.

Araştırmalarda, İşbirlikli Öğrenme tekniklerinin uygulanmasının içerik ve içeriğe bağlı kelime kazanımına olan etkisinin (M18, M19, M20, M22, M25, M26, M27) yanı sıra, öğrencilerin 
okuma-yazma-konuşma ve dinleme becerilerini (M8,M16, M20, M22, M27) olumlu yönde etkilediğini ortaya koymuştur. İşbirlikli Öğrenme teknikleri, öğrencilere üst düzey düşünme becerisi (M7, M8, M15, M21, M33), araştırmaya yönlendirme becerisi kazandırarak (M1, M2, M5, M7, M10, Ö13, M15, M16, M17, M30, M32); problem çözme becerilerini desteklediği ( M3, M6, M7, M8, M14, M15, M16, M21, M25, M35) sonuçlarına ulaşmıştır.

Tablo 6. Çalışmaların Sonuçlarına Ait Veriler

\begin{tabular}{|c|c|}
\hline Sonuçlar & Çalışmalar \\
\hline İşbirlikli Öğrenme, geleneksel metotlara göre daha etkilidir. & $\begin{array}{l}\text { M1, M6, M9, M14, M18, M19, M20, } \\
\text { M21, M22, M23, M25, M26, M29, } \\
\text { M30, M33, M34, M36 }\end{array}$ \\
\hline $\begin{array}{l}\text { İşbirlikli Öğrenme, öğrencilerin akademik başarılarını pozitif } \\
\text { yönde etkilemektedir. }\end{array}$ & $\begin{array}{l}\text { M2, M3, M4, M6, M7, M8, M9, M10, } \\
\text { M13, M14, M15, M17, M20, M22, } \\
\text { M23, M25, M26, M29, M30, M31, } \\
\text { M32, M33, M34 }\end{array}$ \\
\hline $\begin{array}{l}\text { İşbirlikli Öğrenme geleneksel yöntemlerle kıyaslandığın bir } \\
\text { fark yaratmamaktadır. }\end{array}$ & M24, M35 \\
\hline $\begin{array}{l}\text { İşbirlikli Öğgrenmeye dair olumsuz olan bazı öğretmen } \\
\text { görüşleri vardır. }\end{array}$ & M2, M4, M19, M21, M26, M32, M33 \\
\hline $\begin{array}{l}\text { İşbirlikli Öğrenmenin negatif özelliklerine dair öğrenci } \\
\text { görüşleri vardır. }\end{array}$ & $\begin{array}{l}\text { M2, M4, M6, M13, M22, M24, M31, } \\
\text { M32, M33 }\end{array}$ \\
\hline $\begin{array}{l}\text { Sınıf ortamına dair İşbirlikli Öğrenmenin olumsuz yönleri } \\
\text { vardır. }\end{array}$ & M2, M4, M32 \\
\hline $\begin{array}{l}\text { İşbirlikli Öğrenme sosyal becerilere etkisi vardır. } \\
\text { (Öğgrencilerin sosyalleşmelerini sağlayarak, arkadaşlık } \\
\text { ilişkilerini olumlu etkilemektedir.) }\end{array}$ & $\begin{array}{l}\text { M1, M2, M5, M8, M12, M13, M14, } \\
\text { M17, M19, M25, M26, M27, M28, } \\
\text { M29, M30, M31, M32, M33, M34 }\end{array}$ \\
\hline $\begin{array}{l}\text { İşbirlikli Öğrenme iletişimi ve etkileşimi geliştirerek, } \\
\text { işbirliği, olumlu dayanışma, sorumluluk alma, yardımlaşma } \\
\text { gibi konularda olumlu etkiye sahiptir. }\end{array}$ & $\begin{array}{l}\text { M1, M2, M3, M4, M5, M6, M7, M8, } \\
\text { M10, M12, M13, M14, M15, M16, } \\
\text { M17, M18, M20, M22, M23, M25, } \\
\text { M26, M29, M30, M31, M32, M33, } \\
\text { M34 }\end{array}$ \\
\hline $\begin{array}{l}\text { İşbirlikli Öğrenme öğrencilerin } \quad \text { aktif } \\
\text { arttırmaktadır. }\end{array}$ & $\begin{array}{l}\text { M1, M2, M4, M7, M10, M13, M14, } \\
\text { M16, M17, M18, M21, M22, M23, } \\
\text { M25, M26, M28, M30, M31, M32, } \\
\text { M33, M34 }\end{array}$ \\
\hline İşbirlikli Öğrenme eğitimi daha eğlenceli yapmaktadır. & $\begin{array}{l}\text { M1, M5, M6, M13, M16, M17, M21, } \\
\text { M27, M29, M31, M32, M33, M34 }\end{array}$ \\
\hline İşbirlikli Öğrenme uygulamalarında ödül & M10, M13, M29, M30 \\
\hline $\begin{array}{l}\text { İşbirlikli Öğrenmenin içerik ve içeriğe bağlı kelime } \\
\text { kazanımına etkisi vardır. }\end{array}$ & $\begin{array}{l}\text { M18, M19, M20, M22, M25, M26, } \\
\text { M27 }\end{array}$ \\
\hline $\begin{array}{l}\text { İşbirlikli Öğgrenme, öğrencilerin okuma-yazma-konuşma ve } \\
\text { dinleme becerilerini geliştirmede etkilidir. }\end{array}$ & M8,M16, M20, M22, M27 \\
\hline $\begin{array}{l}\text { İşbirlikli Öğrenmenin üst düzey düşünme becerilerine } \\
\text { olumlu etkisi vardır. }\end{array}$ & M7, M8, M15, M21, M33 \\
\hline $\begin{array}{l}\text { İşbirlikli Öğgrenmenin araştırma yönlendirme becerisine } \\
\text { olumlu etkisi vardır. }\end{array}$ & $\begin{array}{l}\text { M1, M2, M5, M7, M10, Ö13, M15, } \\
\text { M16, M17, M30, M32 }\end{array}$ \\
\hline $\begin{array}{l}\text { İşbirlikli Öğrenme öğrencilerin problem çözme becerilerini } \\
\text { desteklemektedir. }\end{array}$ & $\begin{array}{l}\text { M3, M6, M7, M8, M14, M15, M16, } \\
\text { M21, M25, M35 }\end{array}$ \\
\hline
\end{tabular}




\begin{tabular}{|c|c|}
\hline $\begin{array}{l}\text { İşbirlikli Öğrenme, öğrencilerin duyuşsal özellikleri üzerine } \\
\text { etkisi vardır. }\end{array}$ & M1, M5, M6, M18, M33, M35, M36 \\
\hline $\begin{array}{l}\text { İşbirlikli Öğrenme öğrencilerin sosyal bilgiler alanına } \\
\text { yönelik motivasyonlarını olumlu etkilemektedir. }\end{array}$ & $\begin{array}{l}\text { M1, M3, M4, M6, M8, M13, M14, } \\
\text { M16, M23, M28, M29, M31 }\end{array}$ \\
\hline İşbirlikli Öğrenme, öğrencilerin özgüvenini arttırır. & M2, M12, M14, M17, M18, M32 \\
\hline $\begin{array}{l}\text { İşbirlikli Öğrenmenin öz-düzenleme becerilerine etkisi } \\
\text { vardır. }\end{array}$ & M1, M6, M10, M13, M16, M30 \\
\hline İşbirlikli Öğrenmenin öz-yeterlik inancına etkisi vardır. & M30, M34 \\
\hline İşbirlikli Öğrenmenin epistemolojik inanca etkisi vardır. & M36 \\
\hline $\begin{array}{l}\text { İşbirlikli Öğrenme öğrencilerin sosyal bilgiler alanına } \\
\text { yönelik genel tutumlarını ve demokratik tutumlarını olumlu } \\
\text { etkilemektedir. }\end{array}$ & $\begin{array}{l}\text { M9, M11, M13, M14, M15, M25, } \\
\text { M26, M32 }\end{array}$ \\
\hline İşbirlikli Öğrenme tarih bilinci uyandırmada etkilidir. & M1 \\
\hline $\begin{array}{l}\text { İşbirlikli Öğgrenme kültürel mirası koruma } \\
\text { uyandırmada etkilidir. }\end{array}$ & M33 \\
\hline
\end{tabular}

Çalışma sonuçlarına göre sosyal bilgiler derslerinde uygulanan İşbirlikli Öğrenme tekniklerinin, öğrencilerin motivasyon, inanç, öz-güven ve öz-benlik gibi duyuşsal özellikleri üzerinde olumlu bir etkisi olduğunu ortaya koyuştur (M1, M5, M6, M18, M33, M35, M36).

İÖ uygulamalarının, öğrencilerin öğrenmeye karşı motivasyonlarını (M1, M3, M4, M6, M8, M13, M14, M16, M23, M28, M29, M31), öz-güvenlerini arttırarak (M2, M12, M14, M17, M18, M32), özdüzenleme becerilerine (M1, M6, M10, M13, M16, M30), öz-yeterlik (M30, M34) ve epistemolojik inançlarına olumlu etkisinin olduğunu ortaya koymuştur. İşbirlikli Öğrenme teknikleriyle işlenen derslerin, öğrencilerin sosyal bilgiler derslerine yönelik olumlu tutum oluşturarak (M15, M32), öğrencilerin demokratik tutumlarını geliştirdiği (M9, M11, M13, M14), onlarda tarih bilinci oluşturma (M1), kültürel mirası koruma bilinci uyandırmada (M33) ve çok kültürlülük kavramlarını öğrenmelerinde (M25, M26) olumlu bir etkiye sahip olduğu da yine çalışmaların sonuçlarındandır.

\section{Sonuç ve Tartışma}

2010-2020 yılları arasında sosyal bilgiler öğretiminde işbirlikli öğrenme yaklaşımının etkilerinin ortaya konulması amacıyla, çeşitli veri tabanları aracılığıyla Türkiye'de ve diğer ülkelerde son 10 yılda yapılmış olan makaleler, çeşitli değişkenler açısından meta-sentez yöntemi ile incelenmiş ve analiz edilmiştir. Çalışma sonuçlarına göre İşbirlikli Öğrenmenin sosyal bilgiler alanına etkisi üzerine, en fazla çalışma 2015 yılında yapılmıştır. Araştırma kapsamına alınan çalışmaların \%75'den fazlası, 2014-2018 yılları arasında yapılırken; 2010 yılında ise hiç çalışmaya rastlanmamıştır. En fazla çalışma yapan ülke Türkiye (\%55) iken, onu ABD ve Endonezya takip etmektedir. İlgili konuya dair yapılan çalışmaların \%80'den fazlasının Asya ve Afrika ülkelerine ait olması, son yıllarda eğitim bilimleri araştırmaları eğilimlerinin farklı yöne evirilmiş olmasına rağmen, bu bölgelerdeki ülkelerin 
(Türkiye, Endonezya, Pakistan ve Nijerya) alandaki değişim trendlerini geriden takip ettiğini düşünmemize neden olmuştur.

İşbirlikli Öğrenme yönteminin etkisinin incelendiği çalışmaların büyük bir bölümü, İşbirlikli Öğrenme tekniklerine bağlı olarak düzenlenen etkinlik ve faaliyetlerin, öğrencinin (akademik) başarı ve tutumuna etkisini incelemektedir. Çalışmalar, öğrenci görüşleri ve içerik kazanımı gibi diğer bağımlı değişkenlere odaklanmıştır. Literatür incelendiğinde, ülkemizde yapılan tez çalışmalarının da, işbirlikli öğrenme yöntem ve stratejilerinin sosyal bilgiler öğretimi uygulamalarında, öğrencilerin akademik ders başarısı üzerine daha fazla yoğunlaştı̆̆ı görülmektedir (Akbulut, 2013; Uslu, 2016; Bayık, 2016; Yılmaz, 2017). Akademik başarı ve tutumun dışında, motivasyon, üst düzey düşünme becerileri, sosyal beceriler, epistemolojik inanç, öz-yeterlik inancı ve öz-denetim becerileri ve öğretmen görüşleriyle ilgili ise çok az sayıda çalışma tespit edilmiştir. Bu noktada akademik başarıyı ölçen çalışmaların dışında, farklı değişkenler ve örneklem grupları üzerinde çalışmaların yapılmasına ihtiyaç olduğu söylenebilir.

Çalışmalarda kullanılan yöntemlere dair veriler incelendiğinde, çalışmalarda en çok nicel yöntem kullanılmıştır (\% 58.3). Diğer yandan ABD’ye ait olan dört çalışma (M18, M19, M20, M22) nicel yöntemle hazırlanırken, yalnızca bir çalışmada nitel (M27) ve karma yöntemler (M21) kullanılmıştır. Nicel yönteme bağlı olarak deneysel desenle desenlenen farklı örneklem grupları üzerinde etkinlikler yürütülerek; çalışmaların ölçek, anket, görüşme ve gözlem gibi veri toplama araçlarıyla öğrenci ve öğretmen görüşlerinin alındığı verilerle desteklendiği görülmüştür. Bu sonuçlar, bazı çalışmalarla da paralellik göstermektedir. Ross, Morrison ve Lowther (2010) alanda 25 çalışmayı incelemiş, yapılan nicel çalışmaların \% 44, nitel çalışmaların \% 23 ve karma çalışmaların \% 33 oranında olduğunu tespit etmişlerdir. Küçük ve arkadaşları (2013), 1990-2011 yılları arasında alanda 1151 çalışmayı inceleyerek, eğitim teknolojisi alanındaki eğilimi ortaya koymuşlardır. Çalışma sonuçlarına göre nicel araştırma metodu yaklaşık \% 35 oranında kullanılırken, nitel çalışmalar \% 22 ve karma çalışmalar ise \% 10 oranlarında kullanılmıştır. Ayrıca çalışmadaki genel eğilime göre deneysel çalışmalarda bir azalma yaşanırken, nitel çalışmaların ise arttığı tespit edilmiştir. Değerlendirmeye alınan nitel ve karma çalışmaların, nicel çalışmalara göre daha az tercih edilse de özellikle Türkiye'de karma çalışmalara doğru bir yönelim olduğu görülmektedir (Kucuk, Aydemir, Yildirim, Arpacik \& Goktas, 2013). Bu meta-analize dâhil edilen nitel çalışmaların (M1, M4, M5, M7, M8, M13, M16, M17, M31) hepsinin, 2015-2019 yılları arasında yapılmış olması da bu eğilimi doğrular gözükmektedir. Ayrıca bu çalışmalardan (Norveç dışında (M5) kalanlar), Türkiye'ye ait olan üç çalışma (M1, M13, M17) ve Endonezya'ya ait olan dört çalışma (M4, M7, M8, M16, M31) iki Asya ülkesinin, alanda benzer araştırma eğilimine sahip olduğunu bize düşündürtmüştür. Nitel çalışmalarda en fazla eylem araştırması olarak, "classroom action research" yani sınıf eylem araştırması tercih edilmiştir (M1, M7, 
M8, M16, M31). Nitel çalışmalarda sınıf odaklı eylem araştırmalarının yapılması sahaya dönük çalışmaların, diğer nitel desenlere göre daha fazla ön planda olduğunu göstermiştir. Ayrıca çalışmalarda kullanılan model belirtilmiş olsa da genelde modele bağlı olarak kullanılan araştırma desenlerinin belirtilmemesi veya net olarak söylenmemesi, nicel ve nitel yöntemlerin her ikisinin de kullanıldığı karma yöntemlerin nasıl kullanılacağı konusunda, önemli bir karmaşıklık olduğunu bize düşündürtmüştür.

Araştırmalar en çok ortaokul düzeyinde yapılmıştır. Sınıf düzeyinde ise en fazla çalışma 6 . sınıfta, en az çalışma ise ilkokul ve üniversite düzeylerinde gerçekleştirilmiştir. Bunun nedeni olarak sosyal bilgiler alanına dair konuların ilkokulda hayat bilgisi dersi kapsamında genelde örtük öğrenme şeklinde verilmesi, bu yaş grubundaki öğrenciler ile araştırma çalışmaları yürütmenin zorluğu ve araştırmacıların, kolay ulaşılabilir örneklem gruplarını seçmelerinden kaynaklanmış olabilir. Yine üniversite düzeyinde çalışmaların az olmasında ise eğitim kademesinin artmasına bağlı olarak, sosyal bilgiler alanının bir disipline dönüşmesi, İşbirlikli Öğrenme tekniklerinin kalabalık sınıflar ve içeriğin yoğunlaşmasına bağlı olarak uygulanamaması gibi nedenlerle, çalışmaların az olduğu düşünülebilir.

İşbirlikli Öğrenme merkezli olan araştırmaların genelinin öğrenciler üzerinde yapıldığı görülmektedir. Öğretmen ve öğretmen adayları ile yapılan çalışmalar ise oldukça sınırlı kalmıştır. Yalnızca bir çalışma (M4) öğretmenlerin İşbirlikli Öğrenme uygulamalarına dair görüşlerini incelerken yine sadece dört çalışma (M13, M14, Ö17, M32) öğrenci görüşlerini doğrudan incelenmiştir. Çalışmaların örneklem büyüklüğüne baktı̆̆ımız zaman, makalelerin yaklaşı \% 70'i örneklem büyüklükleri $1 \leq \mathrm{N} \leq 100$ arasında alınmıştır. Örneklem büyüklüğü, Küçük ve arkadaşları (2013) tarafından 1990-2011 arasında incelenen çalışmaların, ağırlıklı örneklem büyüklükleri ile de paralellik göstermektedir. Örneklem büyüklüğünün maksimize edilmesi, örnekleme hatasının minimize edilmesine ve araştırma sonuçlarının genellenerek daha güveniler olmasına katkı sunacağı için örneklem gruplarının rastgele seçildiği, öğretmen, öğretmen adayları ve velilerin yer aldığı geniş örneklem büyüklüğüne sahip çalışmalara daha fazla ihtiyaç vardır. Ayrıca sosyal bilgiler öğretiminde İşbirlikli Öğrenme tekniklerinin uygulanmasında karşılaşılan sorunların çözümüne dair daha geniş çaplı olan araştırmalara gereksinim olduğu söylenebilir.

Araştırmalarda en çok kullanılan veri toplama araçlarının ise başarı testleri, ölçekler (özellikle tutum ve görüş), görüşme/mülakat, gözlem ve anket olduğu belirlenmiştir. Video/ses kayıtları, dokümantasyon ve öğrenci günlükleri ise en az tercih edilen araçlar olmuştur. Ölçek kullanan araştırmaların hepsi (M2, M9, M11, M12, M14, M17, M29, M30, M32, M33) Türkiye'ye aittir. Şimşek (2007)'in hazırladığı “Yöntem Görüş Ölçeği” dışında, araştırmacılar başka araştırmacıların hazırladığı ölçekleri kullanmışlardır. Bu ise ülkemizde akademik araştırma düzeyinde ölçek geliştirme noktasında yetersiz kaldığımızı göstermektedir. 
Sosyal bilgiler alanında İşbirlikli Öğrenme yöntem ve tekniklerinin etkisine dair araştırma sonuçları değerlendirildiğinde ise meta-sentez çalısmasına dâhil edilen makalelerin, geleneksel öğrenme yöntemlerine göre uygulanan İşbirlikli Öğrenme tekniklerinin sosyal bilgiler alanında akademik başarı üzerine pozitif bir etki yarattığı ülkemizde yapılan tez çalışmaları ile de paralellik göstermektedir (Göncüoğlu, 2010; Yetkin, 2010; Baş, 2012; Akbulut, 2013; Küçükilhan, 2013; Kaşaveklioğlu, 2013; Bayık, 2016; Uslu, 2016; Yılmaz, 2017). Çalışmalardan yalnızca iki tanesi (M24, M36) İşbirlikli Öğrenmenin geleneksel öğrenme yöntemlerine göre daha üstün olmadığı veya anlamlı bir fark yaratmadığı sonucuna ulaşmıştır.

İşbirlikli Öğrenme modelleri, öğrencilerin sosyal bilgiler öğrenme çıktılarına katkı sağlayarak, öğrenci merkezli öğrenme aktiviteleri ile öğrenmeyi kolaylaştırmaktadır. Çalışmalarda İşbirlikli Öğrenme yönteminin etkisine ilişkin genel olarak, öğrencilerin, sosyal bilgiler alanında bireysel-grup düzeyinde akademik başarılarını arttırarak, grup çalışmasına katılan öğrencilerin, hem derslere hem de arkadaşlarına karşı olumlu bir tutum kazandıkları sonucuna ulaşılmıştır. Bu görüşler, Göncüoğlu (2010) ve Yetkin (2010)'in çalışmaları ile de uyuşmaktadır. Johnson ve Johnson (2002)'da, işbirliğinin beş temel bileşeni arasında, pozitif dayanışma/bağlılık, bireysel sorumluluk, yüz yüze destekleyici iletişim/etkileşim, soysal yetenekler ve grup yönetimi olarak saymışlardır.

Çalışmalar, İşbirlikli Öğrenme yöntem ve teknikleri, grup içerisindeki iletişimi ve etkileşimi yüksek tutarak, grup çalışmalarına katılan öğrencilerin, arkadaşlarıyla öğrenmekten mutluluk duymaları; sorumluluk alma, yardımlaşmayı sağlama, sosyal beceri edinimi, düzenli çalışma alışkanlığı kazanma ve bu gruplarda tartışma, sonuçları analiz etme, geri bildirim sağlama gibi öğrenmeyi daha üst seviyeye çıkaran faaliyetleri desteklemektedir. Bu sonuçlar diğer çalışmalar ile de genel olarak örtüşmektedir (Yllar, 2015; Turgut, 2018). Johnson ve Johnson (2002), özellikle heterojen kooperatif öğrenme gruplarının akademik ilerlemeyi geliştirme ihtiyacı için, üyelerin birbirlerini destekleme, cesaretlendirme ve asiste etme yani birbirlerini destekleme ve yardım etme noktalarında, öğrenmenin niceliğini ve niteliğini arttırarak, grup üyelerinin daha başarılı olduğunu belirtmişlerdir. Günümüzde gittikçe önem kazanan 21. yüzyıl becerileri düşünüldüğünde, yöntemin iletişim, işbirliği, sosyal becerilerin kazanımı, adaptasyon, liderlik, üretkenlik ve sorumluluk duygu ve özelliklerinin kazanımı açısından oldukça önemlidir.

Çalışma sonuçlarında karşılıklı dayanışma, İşbirlikli Öğrenme yönteminde öğrencilerin bilişsel doyuma ulaşabilmeleri için grup çalışmalarına katılmanın yanı sıra, olumlu bir ruh hali, yüksek bir motivasyon, merak ve dikkat çekme gibi faktörlerde oldukça önemlidir. Öğretmenlerin İşbirlikli Öğrenme tekniklerini uyguladıktan sonra, öğrencilerin motivasyonunda önemli bir artış olduğuna dair çalışma sonuçlarına ulaşılması; öğrencilerin motivasyon, merak ve dikkat çekme ile görevlerini yerine getirmedeki azim ve kararlılıkları arasında pozitif bir ilişki olduğuna dair çalışmalar da birbirini 
destekleyici niteliktedir. Sonuçlar, İşbirlikli Öğrenme gruplarına katılan öğrencilerin, sosyal bilgiler kapsamındaki olaylara yaklaşarak, öğrencilerin tarihsel duyarlılık ve empatik bakış açısı kazanmaları ve bu yaklaşımın aktif katılım ve öğrenme ile tarihsel bilinci uyandırması amacına ulaşıldığını göstermiştir. Grup öğrenmelerinde eğlence ve aktif katılımın öğrenmedeki önemini ortaya koyan bazı çalışmalar (M1, M5, M16, M21, M29), grup çalışmalarında oyun temelli öğrenme (gamification) ile hem öğrencilerin sosyal bilgiler müfredatına dayalı bilgisayar oyunu tasarlamaları hem de hazırlanan oyun tasarımları ile öğrencilerin hikâye anlatıcılığı ve rol yapmadaki yeteneklerini ortaya koymuştur. Ayrıca çalışmalar, İşbirlikli Öğrenme tekniklerinin grup içerisindeki öğrencilerin, kendi seçimlerini yapmalarında, çalışmalarını kendi çizdikleri yönde düzenleme gerekliliğini destek olarak, öğrencilerin öz-yeterlik inancını arttırdı̆̆ı; onlara özgüven kazandırarak, öz-düzenleme becerilerine pozitif bir etki yarattığını ortaya koymuştur (M1, M2, M6, M10, M12, M13, M14, M16, M17, M18, M30, M32, M34). Sosyal bilgiler dersinde soyut kavramların kazanımı, öğrencilerin bilişsel yükünün hafifletilmesi, dersi eğlenceli ve çekici kılmak için oyunlaştırma, yaratıcı drama gibi yöntemlerin, işbirlikli tekniklerle harmanlanarak dersin zenginleştirilmesi oldukça faydalı olacaktır.

Söz konusu çalışmalarda en çok kullanılan İşbirlikli Öğrenme teknikleri ise jigsaw, grup araştırması, takım temelli ve oyun temel öğrenme olmuştur. Bu sonuç, Bayır ve Bozkurt (2018), 20052016 yılları arasındaki 22 çalışmayı inceleyerek, en çok jigsaw okuma-yazma-sunma, grup araştırması tekniklerinin kullanıldığı sonucuna ulaştıkları çalışma ile paraleldir. Aynı çalışmaya göre en az kullanılan İşbirlikli Öğrenme teknikleri takım-oyun-turnuva, karşılıklı etkileşim ve öğrenci-takımbaşarı-bölümleriyken; yapılan çalışma ile son yıllarda sosyal bilgiler eğitiminde takım temelli ve oyun temelli çalışmalara daha fazla ağırlık verilmeye başlandığı görülmektedir. Meta-analize konu olan bazı çalışmalarda, İşbirlikli Öğrenme teknikleri hem geleneksel yöntemlerle hem de birbiriyle kıyaslanmıştır. Grup araştırması öğrencilerin akademik başarı (M10) ve demokratik tutum kazanmalarında (M11), jigsaw ve OYU'ya göre daha etkili iken; öğrencilerin sosyal beceri kazanmalarında (M12) bu üç strateji arasında anlamlı bir fark bulunamamıştır. İşbirlikli Öğrenme stratejilerinin, geleneksel yöntemlere göre daha başarılı olduğu ama jigsaw ve GA (M23) veya jigsaw ile BSBÖ arasında (M2, M28) anlamlı bir farkın bulunamadığı; jigsaw, OYS ve grup soruşturması tekniklerinden, jigsaw'ın OYS ve grup soruşturması tekniklerine göre epistemolojik inanç konusunda daha etkili (M36) olduğu sonucuna ulaşan çalışmalar olmuştur.

Çalışmalara göre sosyal bilgiler dersinde İşbirlikli Öğrenme yönteminin uygulanmasının öğrencilerin demokratik tutumlarını geliştirici bir etkisi vardır (M9, M11, M13, M14, M15, M25, M26, M32). Uslu (2016)'nun çalışması da, İşbirlikli Öğrenmenin demokratik tutum geliştirmedeki pozitif etkisi ile örtüşmektedir. Çaycı ve arkadaşları da, öğrencilerin sosyal bilgiler dersi "Adım Adım Türkiye" ünitesinde geçen kavramları öğrenme başarıları üzerindeki etkisinin olumlu olduğu 
sonucuna ulaşmıştır (Çaycı, Demir, Başaran ve Demir, 2007). İşbirlikli Öğrenme stratejilerinin, tarih bilinci kazandırma, soyut olan ve çok kültürlü kavramların öğretilmesi, kültürel mirası koruma bilinci oluşturma gibi bir takım kültürel becerilerin kazandırılmasında ve anlaşılmasında, geleneksel stratejilere göre çok daha etkili bir yöntem olduğunu söyleyebiliriz.

İçerik ve kavram bilgisine dair gelişimin sağlanması için İşbirlikli Öğrenmenin verimli olarak uygulanması ve öğretmenin dışında öğrencilerinde çeşitli açılardan desteklenmesi gerekir. Öğrencilerin konu hakkındaki içerik bilgisinin yeterli olması, kaynakların kolay ulaşılırlığı, uygulama hakkında ön-bilgilendirmenin yapılarak farklı yetenek ve ilgi alanlarına sahip öğrencilerin gruplar içerisinde uygun görev dağılımlarının yapılması bu açıdan oldukça önemlidir. Yine İşbirlikli Öğrenme teknikleri okuma, okuduğunu anlama, yazma, konuşma ve dinleme becerilerinin gelişiminde de oldukça etkili bir öğrenme şeklidir (M18, M19, M20, M22, M25, M26, M27).

ABD kaynaklı çalışmalardan bazıları (M20, M27), kısa adı PACT olan "Promoting Acceleration of Comprehension and Content Through Text" ve metin içerisindeki, sosyal bilgiler içerik bilgisini temel kelimeler, bilgi edinimi, TBL kavrama kontrolü, TBL bilgi edinimi gibi çeşitli açılardan geliştirme amacıyla uygulanan işbirlikli yöntemin, özellikle üç kriter -sınav puanları, sosyal bilgiler alanında okuma ve okuduğunu anlama- açısından başarıyı arttırdığı sonucuna ulaşılmıştır. Okuryazarlık stratejileri, sosyal bilgiler öğretiminin bir parçası olduğundan, işbirlikli öğrenme tekniklerinin kullanımının, öğrencilerin başarısını ve katılımlarını önemli ölçüde arttırdığı söylenebilir. Özellikle ilköğretim çağında, işbirlikçi tekniklerin okuryazarlık stratejileri, sosyal bilgiler öğretiminin bir parçası olduğundan dolayı, öğrencilerin başarısını ve katılımlarını önemli ölçüde arttırmaktadır. Bir diğer çalışma ise (M7), Carousel Feedback ve Yuvarlak Masa işbirlikli öğrenme modellerinin “Higher Order Thinking Skills (HOTS)” (İleri Seviye Düşünme Yetenekleri) ve Sosyal Bilgiler öğrenme çıktılarını arttırabildiğini ortaya koymuştur. Türkiye'de yapılan çalışmalarda geleneksel yöntemlerle, işbirlikli tekniklerin karşılaştırıldığı çalışmalara fazlasıyla rastlanmaktadır. Bu nedenle, sosyal bilgiler dersi açısından farklı işbirlikli tekniklerin üstün ve zayıf yönlerine dair uygulamalı çalışmaların yapılması alana katkı sağlayacaktır.

Yukarıdaki sonuçlar genel olarak değerlendirildiğinde, İşbirlikli Öğrenme merkezli uygulanan stratejilerde öğrencilerin öğrenme, tutum, motivasyon, üst düzey öğrenme, sorumluluk, yardımlaşma, sosyalleşme, işbirliği, arkadaşlık, eğlence, iletişim ve etkileşim konularına daha fazla vurgu yapıldığı görülmektedir. Tüm bu bulgular neticesinde yapılandırmacı bir anlayışla ve İşbirlikli Öğrenme yöntemiyle desteklenen stratejilerin, öğrencilerin sosyal bilgiler alanında başarısını arttırma, sosyal bilgiler alanına dair olumlu tutum ve sosyal becerilerini geliştirmelerinde önemli bir etkiye sahip olduğunu ortaya koymaktadır. 


\section{Öneriler}

Araştırmanın sonuçları doğrultusunda bazı önerilere yer verilmiştir:

1. İşbirlikli Öğrenmenin sosyal bilgiler alanındaki etkisine dair sınıf odaklı olan, sahaya dönük, bütünlük oluşturan ve uzun soluklu hem nitel hem karma çalışmalar yürütülerek, çalışma sayısının az olduğu tasarım ve geliştirme konularına ağırlık verilebilir.

2. Araştırma düzeyinde ölçek geliştirmek için, yüksek lisans ve doktora düzeyinde olan araştırmacıların alabileceği uygulamaya dönük dersler konulabilir.

3. İşbirlikli Öğrenmenin sınırlılıkları hakkında, daha fazla sınıf eylem araştırmaları yapılarak çözümler üretilebilir. Böylece sosyal bilgiler alanında İşbirlikli Öğrenme yöntemini uygulamada, engel olarak görülen problemler araştırılarak ve MEB ile birlikte çalışmalar yapılarak bazı çözümler hayata geçirilebilir.

4. Öğretmenin, eğitim ortamlarını, sınıf içi İşbirlikli Öğrenme uygulamalarına uygun bir şekilde düzenleyerek (M6, M9, M34), gerekli zaman planlamasını yapması (M2, M14, M21, 24, 34) ve kullanılan İşbirlikli Öğrenme teknikleriyle öğrencilerin motivasyonlarını arttıracak yardımcı araçlar işe koşulabilir.

5. Sosyal bilgiler öğreniminde, işbirlikli yöntem ve tekniklerin uygulanması için öğretmenler teşvik edilerek, bu teknikleri aktif bir şekilde uygulamaları için hizmet içi kurslar ve eğitimler verilerek desteklenebilirler.

6. Öğretmenlere, İşbirlikli Öğrenme tekniklerini nasıl kullanacakları örnek etkinlikler ve İşbirlikli Öğrenme uygulamaları yaygınlaştırılabilir. Bu bağlamda, okul zümrelerinde bilgi eksikliklerini giderecek, alan öğretmenlerine özgü spesifik hizmet içi eğitim programları gerçekleştirilebilir.

7. Öğretmenler, İşbirlikli Öğrenme yöntem ve tekniklerini uygularken bütün öğrencileri sürece entegre ederek, aktif olarak katılımı sağlama noktasında iyi birer rehber olmalıdırlar.

8. Öğretmenlerin, özellikle içeriğe uygun İşbirlikli Öğrenme yöntem ve stratejilerin seçilmesi ve öğrencilerin bilişsel yükünü azaltıcı içerik düzenlemesine önem verilmelidir. Böylece sınıf ortamı daha çekici ve eğlenceli bir hale gelerek hem öğrencinin hem de öğretmenin daha aktif olduğu bir sınıf iklimi yaratılmış olur. Bütün bunlar, öğrencinin motivasyonunu arttırarak derse karşı olumlu tutum ve davranış geliştirmesine ve öğrenmenin daha keyifli olmasına yardımcı olacaktır.

\section{Kaynaklar}

Akbulut, G. (2013). 6. Sınıf Sosyal Bilgiler Dersinde İşbirlikli Öğrenme Yöntemi (Birlikte Öğrenme ve Takım Destekli Bireyselleştirme Teknikleri)Uygulamasının Öğrenci Tutum ve Başarısına Etkisi, (Yüksek Lisans Tezi). Muğla Sıtkı Koçman Üniversitesi, Eğitim Bilimleri Enstitüsü: Muğla. 
Anderson, T. (2010). Theories for learning with emerging technologies. En G. Velesianos (Ed.), Emerging technologies in distance education. Edmonton, Canada: AU Press, Athabasca University. pp. 23-40.

Baş, K. (2012) Sosyal Bilgiler Dersinde İşbirlikçi Öğrenme Yönteminin Yedinci Sınıf Öğrenci Başarısına Olan Etkisi, (Yüksek Lisans Tezi). Kilis 7 Aralık Üniversitesi, Sosyal Bilimler Enstitüsü: Kilis.

Bayık, D. (2016). 6. Sınıf Sosyal Bilgiler Dersinde İşbirlikli Öğrenme Yöntemi Destekli Zihin Haritası Tekniğinin Kullanılmasının Öğrencilerin Akademik Başarılarına ve Derse Karşı Tutumuna Etkisi, (Yüksek Lisans Tezi). Fırat Üniversitesi, Eğitim Bilimleri Enstitüsü: Elazığ.

Bayir, O. G., \& Bozkurt, M. (2018). Effectiveness of Cooperative Learning Approaches Used in the Course of Social Studies in Turkey: A Meta-Analysis Study. Online Submission, 4(10), 171-192. https://doi.org/10.5281/zenodo.1313863

Bölükbaş, F. (2014). Jigsaw-IV Tekniğinin Yabancı Öğrencilerin Türkçedeki Temel Zamanları Öğrenmeleri Üzerindeki Etkisi. Uluslararası Türkçe Edebiyat Kültür Eğitim Dergisi, Sayı: 3/3 2014 s.196-209.

Campbell, K. \& Richard A. S. (2014). Major Movements in Instructional Design. Chap. 13 in Online Distance Education: Towards a Research Agenda, edited by Olaf Zawacki-Richter, and Terry Anderson, 345-380. Edmonton: Athabasca University Press.

Çaycı, B., Demir, M. K., Başaran, M., \& Demir, M. (2007). Sosyal bilgiler dersinde işbirliğine dayalı öğrenme ile kavram öğretimi. Kastamonu Ĕ̆itim Dergisi, 15(2), 619-630.

Driscoll, M. P. (2012). Öğretim Süreçleri ve Öğrenme Psikolojisi. Ankara: Anı Yayıncılık.

Efe, R., Hevedanlı, M., Ketani, Ş., Çakmak Ö., ve Efe, H.A. (2008). İşbirlikli Öğrenme Teori ve Uygulama. Ankara: Eflatun Yayınevi.

Ertmer, P. A., \& Newby, T. J. (2013). Behaviorism, cognitivism, constructivism: Comparing critical features from an instructional design perspective. Performance improvement quarterly, 26(2), 4371.

Göncüoğlu, Ö. G. (2010). 6.sınıf Sosyal Bilgiler Dersi Demokrasinin Serüveni Ünitesinin Öğretiminde Drama ve İşbirlikli Öğretim Yöntemlerinin Öğrenci Tutum ve Başarısına Etkisi, (Yüksek Lisans Tezi). Niğde Üniversitesi, Sosyal Bilimler Enstitüsü: Niğde.

Johnson, D. W., \& Johnson, R. T. (2002). Learning together and alone: Overview and meta-analysis. Asia Pacific Journal of Education, 22(1), 95-105.

Kardaş, M.N., ve Cemal, S.(2015). İşbirlikli Öğrenme Tekniklerinin Türkçe Öğretiminde Başarı, Tutum ve Uygulamalara Yönelik Öğrenci Görüşleriyle İlişkisi. Mustafa Kemal University Journal of Social Sciences Institute. Cilt: 12/30, s.231-250 
Kaşaveklioğlu, S. (2013). 7. Sınıf Sosyal Bilgiler Dersinde İşbirliğine Dayalı Öğretim Yönteminin Kullanılmasının Öğrencilerin Akademik Başarı İle Demokratik Tutum ve İnsan Hakları Algılarına Etkisi, (Yüksek Lisans Tezi). Gazi Üniversitesi, Eğitim Bilimleri Enstitüsü: Ankara.

Kucuk, S., Aydemir, M., Yildirim, G., Arpacik, O., \& Goktas, Y. (2013). Educational technology research trends in Turkey from 1990 to 2011. Computers \& Education, 68, 42-50. https://doi.org/10.1016/j.compedu.2013.04.016

Küçükilhan, S. (2013). Öğrenci Takımları-Başarı Bölümleri (ÖTBB) Tekniğinin Sosyal Bilgiler Dersindeki Akademik Başarıya ve Kalıcılığa Etkisi, (Yüksek Lisans Tezi). Afyonkarahisar: Afyon Kocatepe Üniversitesi Sosyal Bilimler Enstitüsü: Afyon.

Loeser, J. W. (2019). Cooperative Learning. Salem Press Encyclopedia.

Özkan, E. (2006).Öğrenmeyi Öğret Bana. Konya: Lokomotif Medya.

Papert, S. \& Harel, I. (1991). Situating constructionism. In S. Papert \& I. Harel (Eds.), Constructionism (s. 1-11). Norwood, NJ: Ablex.

Polat, S. ve Ay, O. (2016). Meta-sentez: Kavramsal bir çözümleme. Eğitimde Nitel Araştırmalar Dergisi- Journal of Qualitative Research in Education, 4(1), 52-64. [Online]: http://www.enadonline.com http://dx.doi.org/10.14689/issn.2148-2624.1.4c2s3m

Ross, S. M., Morrison, G. R., \& Lowther, D. L. (2010). Educational technology research past and present: Balancing rigor and relevance to impact school learning. Contemporary Educational Technology, 1(1), 17-35.

Senemoglu, N. (2018). Gelisim Ögrenme ve Ögretim-Kuramdan Uygulamaya. Ankara: Anı Yayıncılık.

Singh, Y.P. ve Agrawal, A. (2011). Introduction To Co-operative Learning. Indian Streams Research Journal Vol -1, ISSUE -2, March - 2011 ISSN:- 2230-7850.

Slavin, R. E. (2016). Instruction Based on Cooperative Learning. In the Handbook of Research on Learning and Instruction, Eds. R Mayer and P Alexander. London: Taylor \& Francis.

Turgut, B.K. (2018). Sosyal Bilgiler Dersinde Sorumluluk, Yardımseverlik, Hak ve Özgürlüklere Sayg1 Değerlerinin Kazanımında İşbirlikli Öğrenme Modelinin Etkisi, (Doktora Tezi). Atatürk Üniversitesi, Eğitim Bilimleri Enstitüsü: Erzurum.

Uslu, Ö. (2016). 5. Sınıf Sosyal Bilgiler Dersinde İşbirlikli Öğrenme Yönteminin Öğrencilerin Akademik Başarısı ve Demokratik Tutumlarına Etkisi, (Yüksek Lisans Tezi). Mehmet Akif Ersoy Üniversitesi, Eğitim Bilimleri Enstitüsü: Burdur.

Wall, K., Higgins, S.E., Glasner, E., Mahmout, U. ve J Gormally (2009). Teacher Enquiry as a Tool for Professional Development: Investigating Pupils' EffectiveTalk While Learning. The Australian Educational Researcher, Volume 36/2, s.93-118. 
Warrick, W. R. (2001). Constructivism: Pre-historical to post-modern. Ways of Knowing. Final Paper. [Online]: $\quad$ http://www.unhas.ac.id/hasbi/LKPP/Hasbi-KBK-SOFTSKILL-UNISTAFFSCL/Mental\%20Model/constructivism.pdf

Yaşar, Ş., Köse, T. Ç., Göz, N., ve Bayır, Ö. G. (2015). Sosyal bilgiler dersinde öğrenci merkezli öğretmeöğrenme süreçlerinin etkililiği: Bir meta analiz çalışması. Anadolu Üniversitesi Eğitim Bilimleri Enstitüsü Dergisi, 5(1), 38-56.

Yetkin, T. Ö. (2010). İlköğretim 4.Sınıf Sosyal Bilgiler Öğretiminde İşbirlikli Öğrenme Yönteminin Öğrencilerin Akademik Başarısına ve Derse Yönelik Tutumlarına Etkisi, (Yüksek Lisans Tezi). Gazi Üniversitesi, Eğitim Bilimleri Enstitüsü: Ankara.

Yılar, M. B. (2015). Sosyal Bilgiler Dersinde İşbirlikli Öğrenme Yöntemlerinin Öğrencilerin Akademik Başarılarına, Demokratik Tutumlarına ve Sosyal Becerilerine Etkileri (Doktora Tezi). Atatürk Üniversitesi, Eğitim Bilimleri Enstitüsü: Erzurum.

Yıldız, V. A., ve Kılıç, D. (2018). Sosyal Bilgiler Dersi Öğretim Programlarına İlişkin Öğretmen Görüşleri: Bir Meta-sentez Çalışması. Journal of Graduate School of Social Sciences, 22.

Yılmaz, T. (2017). İşbirlikli Öğrenmenin Ortaokul 5. Sınıf Sosyal Bilgiler Dersinde Öğrencilerin Akademik Başarısına ve Sosyal Katılım Becerisine Etkisi, (Yüksek Lisans Tezi). Marmara Üniversitesi, Eğitim Bilimleri Enstitüsü İlköğretim Anabilim Dalı Sınıf Öğretmenliği Bilim Dall, İstanbul.

Yllmaz, K. (2011). The cognitive perspective on learning: Its theoretical underpinnings and implications for classroom practices. The Clearing House: A Journal of Educational Strategies, Issues and Ideas, 84(5), 204-212.

\section{Extended Summary}

\section{The Effect of Cooperative Learning Approach in Social Studies Teaching: Meta-Synthesis Study}

Field studies have a great importance in terms of evaluating the teaching activities in a wider framework and seeing and developing the success of the techniques applied in the field of social studies more clearly. We have not come across a meta-synthesis study showing that collaborative learning methods and strategies have been studied in the last 10 years by making a large-scale review of the literature regarding the effect of social studies. We think that it is important to compile and present the studies in which Cooperative Learning techniques are applied in the social studies course in the form of meta-synthesis, in terms of seeing the effectiveness of the cooperative method in the field of social studies, its place in the literature, and especially to guide and lead educators.

The purpose of this study is to determine the relationship between the scientific studies (articles) conducted in the social studies teaching in 2010-2020 using the "Cooperative Learning" 
method and to provide a bibliography for the literature on the collaborative method. In this regard, a systematic review has been tried to be determined by analyzing the studies in terms of years, countries, purposes, methods used, data collection tools, sample groups and sizes, used techniques and results. Thus, the researchers will be able to see the studies of the last 10 years regarding the field and the method in a holistic way and plan future studies better.

In the study, the meta-synthesis (thematic content analysis) method was used in order to combine the results of studies examining the effect of the cooperative learning approach on social studies course and field. In line with the literature scanned in the study, the views on the effect of cooperative learning method on social studies learning were compiled, synthesized and interpreted with a critical point of view. The universe of the research was scanned with the keywords "cooperative learning, academic achievement, social studies, meta-synthesis study" in BAU, ERIC, Google Scholar and Education Source databases on collaborative learning between 2010-2020. It consists of 36 studies whose full text is accessible. As a result of the searches in the databases, 36 articles were reached, these articles were evaluated and the findings were analyzed and presented. The studies included in the study were coded as "Article1: M1, Article2: M2...", analyzed in detail, transferred to an annotated bibliography table in Excel and presented after being compiled.

Findings of the study revealed that; it is seen that more emphasis is placed on students' learning, attitude, motivation, high-level learning, responsibility, helping each other, socialization, cooperation, friendship, entertainment, communication and interaction in the strategies implemented in Cooperative Learning. As a result of all these findings, it is revealed that the strategies supported with a constructivist approach and the Cooperative Learning method have an important effect on increasing the success of students in the field of social studies and developing their positive attitude and social skills in the field of social studies.

\section{Ek 1. Araştırma Kapsamında İncelenen Çalışmalar}

\begin{tabular}{|l|l|}
\hline $\begin{array}{l}\text { Araştırma } \\
\text { Kodu }\end{array}$ & Araştırmaların Künyesi \\
\hline A1 & $\begin{array}{l}\text { Özcan, E. (2019). İlkokul 4. sınıf sosyal bilgiler dersi tarih konularının aktif öğrenme } \\
\text { modeliyle öğretilmesine ilişkin bir eylem araştırması. Uluslararası Eğitim Araştırmacıları } \\
\text { Dergisi, 2(1), 58-74. }\end{array}$ \\
\hline A2 & $\begin{array}{l}\text { Ilgaz, S., Çalıklar, Ş., Yıldız, E., ve Şimşek, U. (2018). Jigsaw ve Birlikte Soralım Birlikte } \\
\text { Öğrenelim Yöntemlerinin Sosyal Bilgiler Öğretmen Adaylarının Akademik Başarıları } \\
\text { Üzerine Etkisi ve Yöntem ile İgili Görüşleri. Journal of Graduate School of Social } \\
\text { Sciences, 22(1), 307-322. }\end{array}$ \\
\hline A3 & $\begin{array}{l}\text { Herpratiwi, Darsono, Sasmiati, \& Pujiyatli. (2018). Cooperative Learning and Learning } \\
\text { Achievement in Social Science Subjects for Sociable Students. Eurasian Journal of } \\
\text { Educational Research, 75, 81-98. }\end{array}$ \\
\hline A4 & $\begin{array}{l}\text { Widyaningtyas, H., Winarni, R., \& Murwaningsih, T. (2018). Teachers' Obstacles in } \\
\text { Implementing Numbered Head Together in Social Science Learning. International }\end{array}$ \\
\hline
\end{tabular}




\begin{tabular}{|c|c|}
\hline & $\begin{array}{l}\text { Journal of Evaluation and Research in Education, 7(1), } \\
\text { https://doi.org/10.24071/ijiet.2018.020202 }\end{array}$ \\
\hline A5 & $\begin{array}{l}\text { Øygardslia, K. (2018). 'But this isn't school': exploring tensions in the intersection } \\
\text { between school and leisure activities in classroom game design. Learning, Media and } \\
\text { Technology, 43(1), 85-100. DOI: https://doi.org/10.1080/17439884.2017.1421553 }\end{array}$ \\
\hline A6 & $\begin{array}{l}\text { Er, H. (2017). The Impact of Teaching the Subjects under "Science in Time" Unit in the } \\
\text { Social Studies Class in the 7th Grade Using Jigsaw Technique on the Academic Success } \\
\text { of the Students. Universal Journal of Educational Research, 5(5), 838-847. }\end{array}$ \\
\hline A7 & $\begin{array}{l}\text { Yusmanto, H., Soetjipto, B. E., \& Djatmika, E. T. (2017). The Application of Carousel } \\
\text { Feedback and Round Table Cooperative Learning Models to Improve Student's Higher } \\
\text { Order Thinking Skills (HOTS) and Social Studies Learning Outcomes. International } \\
\text { Education Studies, 10(10), 39-49. }\end{array}$ \\
\hline A8 & $\begin{array}{l}\text { Ningsih, Soetjipto, B. E., \& Sumarmi. (2017). Improving the Students' Activity and } \\
\text { Learning Outcomes on Social Sciences Subject Using Round Table and Rally Coach of } \\
\text { Cooperative Learning Model. Journal of Education and Practice, } 8(11), 30-37 \text {. }\end{array}$ \\
\hline A9 & $\begin{array}{l}\text { Şahin, H. Ş., ve Uslu, Ö. U. (2017). 5. Sınıf Sosyal Bilgiler Dersinde İşbirlikli } \\
\text { Öğrenmenin Öğrencilerin Başarıları ve Demokratik Tutumlarına Etkisi. Mehmet Akif } \\
\text { Ersoy Üniversitesi Ĕgitim Fakültesi Dergisi, 2017(41), 184-201. }\end{array}$ \\
\hline A10 & $\begin{array}{l}\text { Yılar, M. B., ve Şimşek, U. (2016). Sosyal Bilgiler Dersinde İşbirlikli Öğrenme } \\
\text { Yöntemlerinin Başarı ve Kalıcıllğa Etkileri. Kastamonu Education Journal, 25(2), 1-15. }\end{array}$ \\
\hline A11 & $\begin{array}{l}\text { Yllar, M. B., ve Şimşek, U. (2016). Sosyal Bilgiler Dersinde Jigsaw, Grup Araştırması ve } \\
\text { Okuma-Yazma-Uygulama Yöntemlerinin Demokratik Tutum Üzerindeki Etkileri. } \\
\text { Sakarya University Journal of Education, 6(2), 172-183. }\end{array}$ \\
\hline A12 & $\begin{array}{l}\text { Yılar, M. B., ve Şimşek, U. (2016). Sosyal Bilgiler Dersinde Farklı İşbirlikli Öğrenme } \\
\text { Uygulamalarının Sosyal Beceriler Üzerindeki Etkileri. Journal of Kirsehir Education } \\
\text { Faculty, 17(3), 835-854. }\end{array}$ \\
\hline A13 & $\begin{array}{l}\text { Yılar, M. B., ve Şimşek, U. (2017). Sosyal Bilgiler Dersinde Farklı İşbirlikli Öğrenme } \\
\text { Yöntemlerinin Uygulamalarına İlişkin Öğrenci Görüşleri. Dicle Üniversitesi Ziya Gökalp } \\
\text { Eğitim Fakültesi Dergisi, (29), 357-373. http://dx.doi.org/10.14582/DUZGEF.781 }\end{array}$ \\
\hline A14 & $\begin{array}{l}\text { Yapici, H. (2016). Use of Jigsaw Technique to Teach the Unit "Science within Time" in } \\
\text { Secondary 7th Grade Social Sciences Course and Students' Views on This } \\
\text { Technique. Educational Research and Reviews, 11(8),773-780. }\end{array}$ \\
\hline A15 & $\begin{array}{l}\text { Korkmaz Toklucu, S., \& Tay, B. (2016). The effect of cooperative learning method and } \\
\text { systematic teaching on students' achievement and retention of knowledge in social } \\
\text { studies lesson. Eurasian Journal of Educational Research, 66, 315-334. } \\
\text { http://dx.doi.org/10.14689/ejer.2016.66.18 }\end{array}$ \\
\hline A16 & $\begin{array}{l}\text { Nurhaniyah, B., Soetjipto, B. E., \& Hanurawan, F. (2015). The Implementation of } \\
\text { Collaborative Learning Model "Find Someone Who and Flashcard Game" to Enhance } \\
\text { Social Studies Learning Motivation for the Fifth Grade Students. Journal of Education } \\
\text { and Practice, 6(17), 166-171. }\end{array}$ \\
\hline A17 & $\begin{array}{l}\text { Çepni, O., \& Öner, S. T. (2015). The Opinions and Self-Assesments of the 7th Grade } \\
\text { Students Regarding the Jigsaw I Technique among the Cooperative Learning Practices } \\
\text { in the Social Studies Course. Journal of Curriculum and Teaching, 4(2), 22-34. }\end{array}$ \\
\hline A18 & $\begin{array}{l}\text { Kent, S., Wanzek, J., Swanson, E. A., \& Vaughn, S. (2015). Team-Based Learning for } \\
\text { Students with High-Incidence Disabilities in High School Social Studies Classrooms. } \\
\text { Learning Disabilities Research \& Practice, 30(1), 3-14. }\end{array}$ \\
\hline A19 & $\begin{array}{l}\text { Wanzek, J., Kent, S. C., Vaughn, S., Swanson, E. A., Roberts, G., \& Haynes, M. (2015). } \\
\text { Implementing team-based learning in middle school social studies classes. The Journal }\end{array}$ \\
\hline
\end{tabular}




\begin{tabular}{|c|c|}
\hline & of Educational Research, 108(4), 331-344. \\
\hline A20 & $\begin{array}{l}\text { Wanzek, J., Swanson, E. A., Roberts, G., Vaughn, S., \& Kent, S. C. (2015). Promoting } \\
\text { acceleration of comprehension and content through text in high school social studies } \\
\text { classes. Journal of Research on Educational Effectiveness, 8(2), 169-188. }\end{array}$ \\
\hline A21 & $\begin{array}{l}\text { Cicchino, M. I. (2015).Using Game-Based Learning to Foster Critical Thinking in } \\
\text { Student Discourse. Interdisciplinary Journal of Problem-Based Learning, 9(2), 57-74. } \\
\text { http://dx.doi.org/10.7771/1541-5015.1481 }\end{array}$ \\
\hline A22 & $\begin{array}{l}\text { Wanzek, J., Vaughn, S., Kent, S. C., Swanson, E. A., Roberts, G., Haynes, M., Fall, A.M, } \\
\text { Stillman-Spisak \& Solis, M. (2014). The Effects of Team-Based Learning on Social } \\
\text { Studies Knowledge Acquisition in High School. Journal of Research on Educational } \\
\text { Effectiveness, 7(2), 183-204. DOI: 10.1080/19345747.2013.836765 }\end{array}$ \\
\hline A23 & $\begin{array}{l}\text { Meral, E., ve Şimşek, U. (2014). Sosyal Bilgiler Dersinde İşbirlikli Öğrenme } \\
\text { Yöntemlerinin 6.Sınıf Öğrencilerinin Akademik Başarılarına Etkisi. Journal of Computer } \\
\text { and Education Research, 2(4), 134-151. }\end{array}$ \\
\hline A24 & $\begin{array}{l}\text { Gürbüz, N., Şimşek, U., ve Berber, K. (2015). İşbirlikli Öğrenme Yönteminin 6. Sınıf } \\
\text { Sosyal Bilgiler Dersinde Öğrencilerin Akademik Başarılarına Etkisi. e-Kafkas Eğitim } \\
\text { Araştırmaları Dergisi, 2(1). }\end{array}$ \\
\hline A25 & $\begin{array}{l}\text { Olukayode, A. S., \& Salako, E. T. (2014). Effect of Jigsaw Technique and Gender on } \\
\text { Students' Attitude to Ethnic Integration and Sustainable Development in } \\
\text { Nigeria. World } \quad \text { Journal } \\
\text { https://doi.org/10.5430/wje.v4n3p46 }\end{array}$ \\
\hline A26 & $\begin{array}{l}\text { Salako, E., Eze, I., \& Adu, E. (2013).Effects of Cooperative Learning on Junior } \\
\text { Secondary School Students' Knowledge and Attitudes to Multicultural Education } \\
\text { Concepts in Social Studies. Education, 133(3), 303-309. }\end{array}$ \\
\hline A27 & $\begin{array}{l}\text { Vaughn, S., Swanson, E. A., Roberts, G., Wanzek, J., Stillman-Spisak, S. J., Solis, M., \& } \\
\text { Simmons, D. (2013).Improving Reading Comprehension and Social Studies Knowledge } \\
\text { in Middle School. Reading Research Quarterly, 48(1), 77-93. }\end{array}$ \\
\hline A28 & $\begin{array}{l}\text { Şentürk, M. (2016). The Effect of Cooperative Learning Methods on Academic Success } \\
\text { in Social Studies Course. Journal of Computer and Education Research, 8, } 205 .\end{array}$ \\
\hline A29 & $\begin{array}{l}\text { Öztürk, Ç.\& Korkmaz, Ö (2020). The Effect of Gamification Activities on Students' } \\
\text { Academic Achievements in Social Studies Course, Attitudes towards the Course and } \\
\text { Cooperative Learning Skills. Participatory Educational Research, 7(1), 1-15. }\end{array}$ \\
\hline A30 & $\begin{array}{l}\text { Arslan, A. (2012). Ayrılıp Birleşme IV Tekniğinin Erişiye, Öz Yeterlik İnancına ve Öz } \\
\text { Düzenleme Becerisine Etkisi. Uluslararası Yönetim İktisat ve İşletme Dergisi, 7(13), 369- } \\
385 .\end{array}$ \\
\hline A31 & $\begin{array}{l}\text { Miaz, Y. (2015). Improving Students' Achievement of Social Science By Using Jigsaw } \\
\text { Cooperative Learning Model at Primary School. IOSR Journal of Research E Method in } \\
\text { Education (IOSR-JRME), 5(4), 1-7. }\end{array}$ \\
\hline A32 & $\begin{array}{l}\text { Seyhan, A. S., ve Şimşek, U. Ş. (2019). Jigsaw Yönteminin Öğrencilerin Tarih Dersine } \\
\text { Karşı Tutumlarına Etkisi ve Yöntem Hakkında Öğrenci Görüşleri. Ahi Evran } \\
\text { Üniversitesi Kırşehir Eğitim Fakültesi Dergisi, 2019(2), 631-672. }\end{array}$ \\
\hline A33 & $\begin{array}{l}\text { Seyhan, A. (2017). Grup Araştırması Tekniği'nin Öğrencilerin Tarihi Çevre Bilgisi ve } \\
\text { Kültürel Mirası Koruma Bilinci Üzerinde Etkisi. International Journal of Education } \\
\text { Technology and Scientific Researches, 2(3), 87-99. }\end{array}$ \\
\hline A34 & $\begin{array}{l}\text { Ocak, G., ve Küçükilhan, S. (2014). İşbirliğine Dayalı Öğrenci Takımları-Başarı } \\
\text { Bölümleri (ÖTBB) Tekniğinin Sosyal Bilgiler Dersindeki Akademik Başarıya ve } \\
\text { Kalıcılığa Etkisi. (Turkish). E-International Journal of Educational Research, 5(4), 17-40. }\end{array}$ \\
\hline A35 & Parveen, Q., Mahmood, S. T., Mahmood, A. \& Arif, M. (2011). Effect of cooperative \\
\hline
\end{tabular}




\begin{tabular}{|l|l|}
\hline & $\begin{array}{l}\text { learning on academic achievement of 8th grade students in the subject of social studies. } \\
\text { International Journal of Academic Research, 3(1), 950-954. }\end{array}$ \\
\hline A36 & $\begin{array}{l}\text { Şimşek, U. (2013). The Effects of Cooperative Learning Model on Students' } \\
\text { Epistemological Beliefs in Civics Lesson/İşbirlikli Öğrenme Modelinin Vatandaşlık } \\
\text { Dersi Öğrencilerinin Epistemolojik İnançları Üzerindeki Etkileri. e-Uluslararası Eğitim } \\
\text { Araştırmaları Dergisi, 4(1), 29-46. }\end{array}$ \\
\hline
\end{tabular}

